\title{
La arquitectura eclesiástica en Álava y Treviño durante los siglos XII-XIII: promotores, constructores y significados en un momento de transición
}

\author{
Ecclesiastical architecture in Álava and Treviño during the $12^{\text {th }}$ and $13^{\text {th }}$ \\ centuries: promoters, builders and meanings in a transitional moment
}

\author{
Egoitz Alfaro Suescun ${ }^{1}$ \\ Universidad del País Vasco / Euskal Herriko Unibertsitatea
}

\begin{abstract}
RESUMEN
En este artículo se reflexiona sobre la edificación de iglesias durante los siglos XI I y XI II en Álava y Treviño, tratando de rastrear las transformaciones que se dieron en la naturaleza de sus promotores, el modelo organizativo de sus constructores y sus funciones y significados. Para ello se analizan más de un centenar de templos, definiendo variables constructivas y agrupándolos en tres momentos a través de las marcas de talla: periodo 1 (1100-1250), periodo $2(1220-1250)$ y periodo 3 (1220-1300). La relación entre estos periodos y las variables constructivas señaladas muestran dos grandes cambios en la arquitectura eclesiástica durante estos siglos respecto a la época anterior, siendo el siglo XII una suerte de etapa de transición. Dichos cambios se identifican tanto en la demanda, con iglesias cada vez más a sequibles, rápidas de erigir y menos complejas, como en la oferta, con templos cada vez más homogéneos.
\end{abstract}

Palabras clave: iglesias; Plena Edad Media; arqueología de la arquitectura; cronotipología; románico.

\begin{abstract}
This paper presents a reflection on church building in Álava and Treviño regions (north-central Spain) during the $12^{\text {th }}$ and $13^{\text {th }}$ centuries. The study aims at tracking the transformations occurred in the promoters' idiosyncrasy, the builders' organizational model and both the function and meaning of these temples. More than a hundred cases have been analyzed to this end, so as to determine the variables involving their construction. Three main phases have been established according to changes documented in stonemasonry: period 1 (1100-1250), period $2(1220-1250)$ and period $3(1220-1300)$. The combined assessment of both the aforementioned variables and phases shows the existence of two major shifts in the ecclesiastical architecture of these centuries with regard to the previous period, constituting the $12^{\text {th }}$ century itself kind of a transitional stage. These changes are seen in both the demand -economically, temporally and structurally more feasible buildings- and the supply increasingly homogeneous temples-.
\end{abstract}

Key words: Churches; High Middle Ages; Archaeology of Architecture; Chronotypology; Romanesque

Recibido: 30-01-2017. Aceptado: 23-07-2017. Publicado online: 19-12-2017

Cómo citar este artículo / Citation

Alfaro Suescun, E. 2017: "La arquitectura eclesiástica en Álava y Treviño durante los siglos XII-XIII: promotores, constructores y significados en un momento de transición", Arqueología de la Arquitectura, 14: e057, doi: http://dx.doi.org/10.3989/arq.arqt.2017.010.

\section{Copyright}

(c) 2017 CSIC. Este es un artículo de acceso abierto distribuido bajo los términos de una licencia de uso y distribución Creative Commons Attribution (CC-by) España 3.0. 


\section{INTRODUCCIÓN. IGLESIAS ROMÁNICAS, IGLESIAS PRERROMÁNICAS}

De forma general, el objeto de análisis del presente artículo es la arquitectura eclesiástica de los siglos XII al XIII en el Territorio Histórico de Álava y el enclave de Treviño. Su objetivo, inferir quiénes, por qué y de qué manera construyeron los edificios de culto a lo largo de estos dos siglos. Trataremos para ello de diferenciar talleres, técnicas o el empleo de materiales concretos asociados a promotores, proyectos y momentos constructivos diversos, comparándolos además con lo que se conoce a este respecto del periodo inmediatamente anterior. ${ }^{2}$

Afortunadamente este objeto de estudio, en los marcos espaciales y cronológicos definidos, no es poco

\footnotetext{
2 Este texto deriva de las ideas desarrolladas en la tesis doctoral defendida por E. Alfaro en enero de 2016 en la Universidad del País Vasco (UPV/EHU). Dicho trabajo, titulado La formación de la red parroquial en Álava y Treviño. Evidencias desde la arqueología (siglos XI-XIII), se encuentra actualmente inédito. La autoría de fotografías y gráficas corresponde también al autor.
}

generoso. $\mathrm{Y}$ es que a la ventaja, inherente a todos los trabajos sobre arqueología de la arquitectura, de no necesitar tantos recursos para acceder al registro material como en una excavación del subsuelo se añade el gran número de restos existentes en alzado, adscritos al estilo románico, que en nuestro territorio se extiende a lo largo de los siglos XII y XIII. ${ }^{3}$ Esta abundancia contrasta con la escasez de restos de la arquitectura eclesiástica anterior, la prerrománica, cuya identificación material se produjo en nuestro territorio hace apenas dos décadas y gracias a los trabajos vinculados a la arqueología de la arquitectura (Azkarate 1995; Azkarate et al. 1995; Solaun 2003; Azkarate y Sánchez Zufiaurre 2003; Sánchez Zufiaurre 2007).

\footnotetext{
3 Los historiadores del arte convienen en iniciar la expansión del románico en Álava y Treviño en el siglo XII (López de Ocáriz y Martínez de Salinas 1988: 42-45; Gómez Gómez 1995-1997: 242; Portilla 1984: 51). El único que se aventura con una fecha anterior (finales del siglo XI-comienzos del XII) es J. J. López de Ocáriz y para el caso concreto de Nuestra Señora de Elizmendi (López de Ocáriz 2014: 41).
}

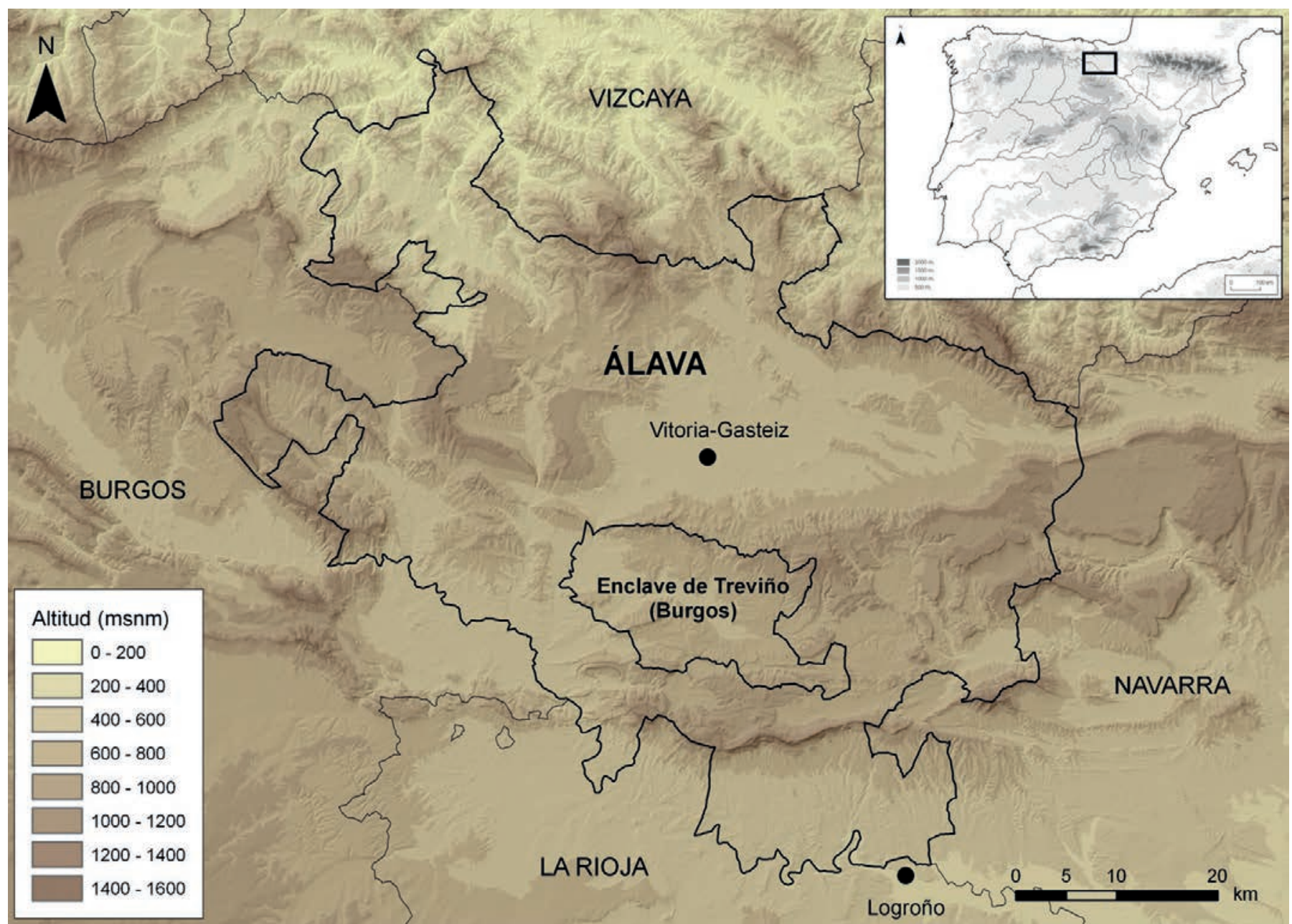

Fig. 1. Mapa contextualizando nuestro marco geográfico de estudio: el Territorio Histórico de Álava y el enclave de Treviño (Autor: J. Ordoño). 


\section{Cuantificación y características}

En este sentido, L. Sánchez Zufiaurre ha identificado en Álava y Treviño, a través de diversos trabajos, 26 iglesias con restos prerrománicos ${ }^{4}$ datados en un amplio arco temporal entre los siglos IX y XII. A partir de variables constructivas concretas, el autor distribuyó todos estos templos en seis grupos, de los que únicamente se analizarán tres, al ser coincidentes con la cronología de nuestro trabajo.

Las tres iglesias que componen el grupo 4 fueron erigidas siguiendo un sistema productivo de albañilería, empleándose material local extraído por capas naturales en el aparejo y sepulcros reutilizados en esquinales y vanos. Se fechan, gracias al post quem de los sepulcros (siglos IX-X) y el ante quem de la obra románica (siglos XII-XIII) en una amplia horquilla cronológica comprendida entre los siglos X y XII (Sánchez Zufiaurre 2007: 274-277).

Las siete ${ }^{5}$ iglesias que componen el grupo 5 son muy heterogéneas, siendo su único rasgo en común la técnica constructiva de los paramentos, realizados con una mampostería de bajo coste con materiales locales y constructores no especializados. Evidentemente esto supone un hándicap añadido a la hora de establecer una cronología, ya que es una forma de construir que, como el mismo autor admite, "nunca dejó de ser utilizada, pudiendo ser identificada en construcciones de las más diversas épocas hasta la actualidad". De hecho, añade que "desde el punto de vista técnico estamos ante un grupo cuyos miembros pueden ser coetáneos a cualquiera de los demás grupos" (Sánchez Zufiaurre 2007: 279). Propone, en cualquier caso, el siglo XI como datación genérica, al menos para algunos de sus templos. ${ }^{6}$

El grupo 6 incluye seis templos y se caracteriza por esquinales realizados con mampuestos semielaborados, aparejos con material local extraído por capas naturales

\footnotetext{
4 De éstas, 24 fueron publicadas en su tesis doctoral (Sánchez Zufiaurre 2007) y las dos restantes en un trabajo posterior sobre los talleres constructivos en el Condado de Treviño (Sánchez Zufiaurre 2012).

5 Fueron ocho en la publicación de su tesis doctoral, pero en la referida obra de 2012 se trasladó la iglesia de Nuestra Señora de la Asunción de Valluerca del grupo 5 al 2 (Sánchez Zufiaurre 2009: 87-88).

6 L. Sánchez trata de solventar los problemas referidos recurriendo a los análisis de mortero realizados en algunos de los templos prerrománicos. Destaca dos conclusiones reseñables. En primer lugar y a partir de la coincidencia de sus morteros, establece la contemporaneidad entre las iglesias de Goiuri-Ondona y Eribe, esta última del grupo 4. En segundo lugar, determina la existencia de un centro productor de morteros que operaba en el noroeste de la provincia y que se surtía de las arenas procedentes del cauce del Bayas al sur del diapiro de Murgia. Estos artesanos habrían aportado la argamasa para la construcción de diversas iglesias de los grupos 4, 5 y 6 . Al compartir este mismo origen el autor da por hecho cierta contemporaneidad en la edificación de éstas, aunque ello no le permite acotar la pertinaz cronología del grupo 5, debido a las amplias horquillas temporales de estos grupos (Sánchez Zufiaurre 2007: 280-281, 304-305).
}

o semielaborado, el empleo del picón como instrumento de labra y la presencia de saeteras a los pies, algunas de ellas con evidencias del uso de tallante. Han sido datadas en los siglos XI y XII.

Sin embargo, la argumentación ofrecida por el autor para establecer dicha horquilla cronológica es, a nuestro parecer, poco sólida. En primer lugar, infiere conclusiones parciales de las menciones documentales en las que se apoya. Así, como Otazu es citado en la Reja de San Millán, presupone la existencia de un centro de culto en la aldea para comienzos del siglo XI. Del mismo modo, como Gazeta y Acilu no son mencionadas en este documento cuando otras aldeas de su alrededor sí (Alegría, Elburgo y Añua; Arrieta y Adana respectivamente), da por hecho que las localidades no existían en este momento $\mathrm{y}$, evidentemente, tampoco los templos, con lo que lo utiliza a modo de post quem para el grupo (Sánchez Zufiaurre 2007: 284-285). Consideramos que interpretar un documento complejo como la Reja de forma tan literal es un error. ${ }^{7} \mathrm{Al}$ fin y al cabo se trata de un listado de aldeas que debían pagar un tributo al monasterio de San Millán de la Cogolla, no un censo exhaustivo de las localidades alavesas existentes en la primera mitad del siglo XI. Que Gazeta y Acilu no lo pagasen cuando las aldeas de su entorno lo hacían no puede servir de argumento para cuestionar su existencia. Igualmente, la simple mención en el documento tampoco debería emplearse para admitir la presencia de un edificio de culto en el lugar.

$\mathrm{Su}$ segundo argumento pone en relación los elementos defensivos que se repiten en las iglesias de este grupo, las dos líneas de saeteras a los pies, y la existencia de un posible dextros en Gopegi con el modelo historiográfíco del ensagrerament catalán (Sánchez Zufiaurre 2007: 140-141 y 285-287). Éste se basa en un presunto pacto a partir del siglo XI entre los obispos y el campesinado, con la sagrera como institución central, para proteger a éstos últimos de la apropiación violenta del excedente campesino por parte de los señores feudales. Sin pretender cuestionar la existencia del dextros o la iniciativa unitaria de las iglesias de este grupo, creemos que hay ciertas matizaciones que deberían tenerse en cuenta. Por un lado, se desconoce el momento en que se fundaron la iglesia y el dextros de Gopegi. Las sagreras catalanas se fechan fundamentalmente entre mediados del siglo XI y mediados del XII, reduciéndose sustancialmente el número de noticias documentales al

\footnotetext{
Sobre los problemas en el significado y comprensión de este documento véase Pastor 2011: 57-60.
} 
respecto a partir de 1175 (Farías 1993: 113), pero nada sabemos sobre si esta cronología, o el propio marco interpretativo, son válidos también para nuestra geografía. Por otro lado, historiadores que defienden el modelo interpretativo tradicional de $\mathrm{P}$. Bonnassie han rebajado la influencia de la violencia señorial en el desarrollo de la sagrera (Farías 2007: 62), por lo que la aparición de estos templos con funciones poliorcéticas no tiene por qué estar relacionada con estos procesos históricos ni, evidentemente, con sus cronologías.

A estas evidencias prerrománicas hay que sumar las incluidas dentro del estilo románico, mucho más numerosas, sobre todo en lo que se refiere al siglo XIII. Según la Enciclopedia del Románico se contabilizan 224 iglesias con restos arquitectónicos románicos en el territorio analizado: 207 en Álava (García Guinea y Pérez González 2011) y 17 en Treviño (García Guinea y Pérez González 2002).

A pesar de que el estilo románico se ha llegado a definir en nuestro territorio como "bastante unitario pese a las escuelas locales" (López de Ocáriz y Martínez de Salinas 1988: 18), las publicaciones al respecto no se han prodigado en ofrecer rasgos concretos que compartan todas (o la mayor parte de) sus iglesias y que establezcan sin ambages su adscripción al grupo estilístico. ${ }^{8}$ M. Portilla, por ejemplo, consideraba que las características de los templos del románico alavés eran las plantas rectangulares y un predominio de las cabeceras rectas, los muros de mampostería, los arcos apuntados y las cubiertas de bóveda de cañón apuntado (Portilla 1984: 47). Como vemos, nada demasiado específico.

Con todo, estos autores coinciden en diferenciar varias formas en las que el estilo se materializa en Álava, dependiendo de variaciones cronológicas (románico primitivo, pleno, tardío/protogótico) o por diferencias en los promotores, la inversión y/o la geografía (románico monumental, rural). Estas categorías adolecen, sin embargo, de falta de concreción, siendo sus límites confusos, ya que se elaboran en base a la tipología o la decoración. Muchas veces la pertenencia de una iglesia a una u otra está poco justificada cuando no roza directamente la arbitrariedad. ${ }^{9}$

\footnotetext{
8 Resulta significativo que en esa misma publicación las iglesias del siglo XIII se analicen por zonas geográficas debido a su gran variedad de caracteres y la dificultad de extraer rasgos generales que las definan.

9 J. J. López de Ocáriz y F. Martínez de Salinas consideran las cabeceras semicirculares y el primitivismo de la decoración de los capiteles, más que el apuntamiento de los arcos, rasgos del románico primitivo que emplazan de forma genérica en el siglo XII (López de Ocáriz y Martínez de Salinas 1988: 42-45). M. Portilla también pone en duda el empleo del apuntamiento de los vanos como criterio de datación, aunque defiende que las portadas de casi todos los templos de finales del siglo XII e inicios del XIII utilizaban arcos de medio punto, mientras que en el siglo XIII predominaban los apuntados (Portilla 1984: 51).
}

\section{El problema conceptual del románico}

Estas carencias en la definición del románico y la ausencia de límites precisos en sus categorías lastran, bajo nuestro punto de vista, su empleo entre arqueólogos. Pese a lo cual somos conscientes del grado de aceptación que tiene el término entre ellos y cualquier otro historiador que se ocupe del patrimonio medieval.

T. O'Keeffe, en su obra Archaeology and the PanEuropean Romanesque, llama la atención sobre la ausencia de una definición que verdaderamente englobe todas las construcciones etiquetadas como románicas y la escasa actitud crítica que se ha dedicado a este aspecto fundamental:

There is no definition in the specialist literature which captures essences of all those buildings and groups of buildings [...] Ironically (and revealingly), scholars have found it considerably easier to identify buildings as examples of Romanesque than to define the boundaries within which they make those identifications. [...] by-passing definition is an option that is not really open to participants in Romanesque studies. It is not because we actually need a definition per se; after all, to argue that we need a definition is to imply that the construct is inherently a good and accurate one, a viewpoint which I am contesting. Rather, it is because the unspoken, uncritical, definition is problematic in our intellectual engagement with the corpus of architecture (O'Keeffe 2007: 26-27 y 56-57).

Este párrafo del arqueólogo irlandés recoge perfectamente las limitaciones apuntadas sobre la arquitectura románica alavesa: "No hay una definición en los textos de los especialistas que capture las esencias de todos esos edificios o grupo de edificios".

En cualquier caso, no tratamos con esto de negar la existencia de paralelos, semejanzas y centros de influencia en edificios, esculturas o pinturas considerados románicos. Así como tampoco buscamos refutar la influencia directa o indirecta sobre estas arquitecturas de eventos históricos como la promoción y desarrollo del Camino de Santiago o la Reforma Gregoriana, por poner dos ejemplos a los que se asocia el románico. Queda fuera de los límites de este artículo.

Nuestra única pretensión es poner el acento sobre la carga conceptual inherente al románico y sus complicaciones para referirse a un tipo de arquitectura específica y cerrada. Por ello, y siendo el objetivo del trabajo 
desentrañar las claves de la arquitectura eclesiástica de los siglos XII y XIII, hemos considerado más prudente aproximarnos al objeto de estudio evitando dicho término y sus connotaciones.

\section{ESTUDIO. LAS IGLESIAS DE LOS SIGLOS XII-XIII ${ }^{10}$}

Para delimitar la muestra de análisis se partió de las obras generales del románico antes referidas, que han identificado un total de 224 iglesias, recordemos, para Álava y Treviño. Sin embargo y dado que se trataba de una cifra considerable, se optó por prescindir de todos aquellos restos aislados y probablemente descontextualizados (portadas, vanos y canecillos en su mayoría) para obtener una más realista y abarcable que permitiera, además, definir los volúmenes y las técnicas constructivas de estas iglesias. Se excluyeron asimismo todos aquellos templos grandes y complejos vinculados a comunidades monásticas de entidad (Santa María de Estíbaliz y Santa María de los Reyes en Laguardia), los que no podían ser debidamente estudiados por haberse convertido en viviendas (Santa María de Sallurtegui y Nuestra Señora de Ula en Salvatierra) o no ser accesibles (las parroquias de Villanueva de Valdegovía y Morillas) y los que, tras el estudio, evidenciaron que no disponían de fases conservadas de los siglos XII-XIII ${ }^{11}$ o eran inaccesibles por su estado de deterioro (antigua parroquia de Santa Ana en Goiain, Legutio). En cuatro de estas iglesias se identificaron, finalmente, dos fases constructivas diferentes correspondientes a este momento, con lo que la muestra final la integraron 112 fases de 108 iglesias, 100 en Álava y 8 en Treviño (García Guinea y Pérez González 2002 y 2011).

En cualquier caso, el empleo de estas obras generales sobre el románico sirvió únicamente para identificar

\footnotetext{
Es cierto que algunas fases constructivas consideradas prerrománicas se extienden hasta el siglo XII, pero al haber sido ampliamente estudiadas (Sánchez Zufiaurre 2007) y al ser afectadas por una reforma posterior de los siglos XII-XIII no serán tenidas en cuenta.

${ }_{11}$ Concretamente, las parroquias de San Juan Ante Portam Latinam en Crispijana (Vitoria-Gasteiz), San Martín en Eribe (Zigoitia), y las ermitas de Nuestra Señora de Beolarra en Markinez (Bernedo) y San Pedro de Quilchano en Argomaniz (Elburgo). Esta última ermita fue excavada a mediados de los 90, constatándose que del templo del siglo XII únicamente quedaba la zapata de cimentación y dos ventanales remontados en un momento posterior (Azkarate et al. 1995: 68). Se ha excluido también la parroquia de San Pedro de Ascarza (Treviño) por considerar, con reservas, que los elementos conservados aparentemente de esta cronología (remate, vanos del ábside y portada) fueron remontados en un momento posterior.
}

los edificios objeto de análisis, puesto que el acercamiento monumentalista que realizan de cada iglesia obvia su naturaleza pluriestratificada y se centra en los elementos más destacables desde un punto de vista estético, estuvieran o no in situ. Fue necesario, por tanto, visitar cada templo para realizar una lectura estratigráfica simplificada ${ }^{12}$ que se limitó a sus paramentos exteriores, salvo los casos puntuales en los que se pudo acceder al interior del templo, o a las fotografías publicadas de éste. Se tuvieron en consideración, asimismo, las lecturas estratigráficas publicadas sobre las iglesias de la muestra (Azkarate 1995; Núñez 2000; Sánchez Zufiaurre et al. 2002; Solaun 2003; Murillo 2004; Sánchez Zufiaurre 2004; Sánchez Zufiaurre 2007; Sánchez Zufiaurre y Benedet 2009a; Sánchez Zufiaurre y Benedet 2009b; Sánchez Zufiaurre y Neira 2009; Alfaro 2009; Sánchez Zufiaurre 2012), además de alguna todavía sin publicar, gracias a la generosidad de su autor (Ajamil 2012).

En cada una de estas lecturas se delimitaron los paramentos asignables a los siglos XII y XIII y se codificaron sus caracteres constructivos. Todo ello con el objetivo de definir grupos de iglesias que compartiesen los mismos rasgos y reflejasen, por ende, su sincronía y una génesis similar. Se siguió para ello a los autores italianos que, desde los años 70 y a través del ISCUM (Istituto di Storia della Cultura Materiale) de Génova, pusieron los fundamentos de la cronotipología asociada a la arqueología de la arquitectura.

Este método de estudio experimental y deductivo, que tiene como fin último la datación, se ocupa de los artefactos realizados en serie (en su sentido preindustrial), sujetos a las reglas del mercado y destinados a satisfacer necesidades concretas. En estas producciones tanto el conformismo de los promotores como la tendencia de la mano de obra de abreviar el trabajo, por las ventajas que implicaba, a través de la repetición de los mismos procedimientos técnicos, determinó la estabilización de las formas y de los efectos decorativos. Ello no suprimía, naturalmente, el impulso hacia el cambio, ligado por lo general a la necesidad del artesano de personalizar sus productos o a la vanidad del promotor para distinguir su obra del resto (Ferrando et al. 1989: 650).

Las variables constructivas que se codificaron para la correcta definición de los cronotipos tenían en cuenta tanto las técnicas constructivas, los materiales y los instrumentos

\footnotetext{
12 Similar a la "lettura veloce de los principales momentos constructivos" definida en Azkarate y Sánchez Zufiaurre 2003: 30 e inspirada en la Scheda di Archiviazione Veloce y el concepto de gradualidad de la documentación de Brogiolo 1988: 33-34, 40.
} 
como las formas de sus motivos decorativos. En cada caso, y tras la delimitación estratigráfica de los paramentos de los siglos XII-XIII, se rellenó una ficha marcando todos estos caracteres arquitectónicos, acompañándose todo ello de una meticulosa documentación fotográfica.

\section{Variables constructivas}

En total se han diferenciado 11 variables que toman en consideración, como se ha dicho, las técnicas constructivas, los materiales, los instrumentos de talla y los patrones decorativos.

- El aparejo de los muros contempla siete posibilidades, en función del tratamiento y el origen de los bloques de piedra. La sillería (1) es la opción que más inversión y trabajo exige, estando compuesta por bloques paralelepípedos. ${ }^{13}$ El sillarejo (2) lo forman piezas casi paralelepípedas que cuentan con ciertas imperfecciones que impiden su consideración de sillares. La mampostería escuadrada (4) se refiere a aquellos bloques suficientemente trabajados como para contar con caras uniformes y aristas rectas, sin llegar al nivel de sillares o sillarejos. La mampostería semielaborada (5) evidencia un tratamiento todavía menor, limitándose a un desbaste básico para buscar cierta regularidad entre las piezas. Entre el material sin trabajar diferenciamos los bloques extraídos por capas naturales (6), lo que se conoce como spaccatura en italiano, y el material recogido (7), en el que predominan los cantos de río. Finalmente, el material reutilizado (8) incluye todas las piezas reaprovechadas de estructuras anteriores expoliadas.

- El aparejo de los esquinales retoma cinco de estas mismas opciones: sillería (9); sillarejo (10); mampostería escuadrada (11); bloques extraídos por capas naturales (12); material reutilizado (13).

- El aparejo de los vanos engloba, dependiendo del tipo de bloque empleado en la factura de las saeteras y/o ventanales (no se tienen en cuenta los vanos de acceso), las siguientes siete posibilidades: sillería (23); sillería y piezas escultóricas (24), cuando además de bloques paralelepípedos se utilizan otras

\footnotetext{
13 T. Mannoni estableció que los sillares (conci ortogonali) deben cumplir dos reglas. Primero, todas sus caras han de constituir un plano rectangular. Segundo, todas las caras tienen que ser perfectamente perpendiculares con sus cuatro caras colindantes, cuestión que se logra con el uso de la escuadra (Mannoni 1997: 15-16).
}
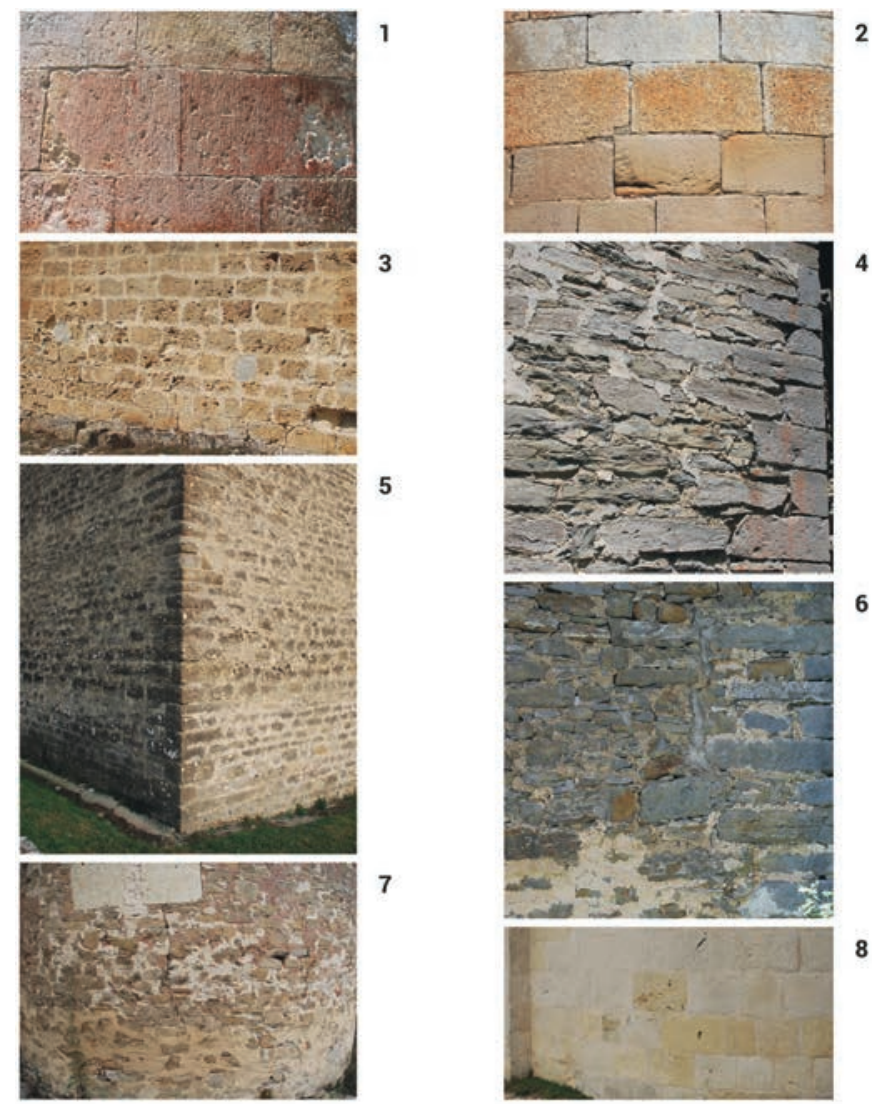

Fig. 2. Algunos de los aparejos de muros y esquinales: (1) sillería de caliza paleocena (Markinez); (2) sillería de caliza paleocena y arenisca miocena (San Martín de Zar); (3) sillarejo de travertino (Ribera); (4) mamp. semielaborada y spaccatura con esquinales de sillarejo (Katadiano); (5) mamp. semielaborada y spaccatura con esquinales de mamp. escuadrada (Ntra. Sra. de Ayala, AlegríaDulantzi); (6) material recogido y esquinales de mamp. escuadrada (Etxabarri-Kuartango); (7) material recogido (Valluerca); (8) material reutilizado (Ullíbarri-Arana).

piezas talladas, generalmente con fines decorativos (impostas, trasdoses, columnas, etc.); sillería, mampostería y piezas escultóricas (25); sillería y mampostería de diverso tratamiento (26); elementos reutilizados (27); elementos reutilizados y mampostería (28); mampostería (29).

- La morfología del ábside incluye tres alternativas: recto (20), con la fachada E perpendicular a los muros N y S de la nave; semicircular (21); ochavado (22), con varios paños rectos e iguales formando un polígono.

- La morfología de la portada está determinada por la presencia de un arco o de arquivoltas y por sus apoyos. Se diferencian cuatro opciones, de mayor a menor complejidad arquitectónica: arquivoltas y columnas (30); arquivoltas y baquetones (31), siendo estos últimos molduras circulares y estrechas que generalmente tratan de imitar columnas; arquivoltas 
y jambas de arista (32), sin apoyos elaborados; arco y jambas de arista (33), la opción más sencilla.

- La tipología de los vanos orientales tiene en cuenta el tipo de vanos presentes en el paño oriental, diferenciando saeteras (34), ventanales (35) y óculos (36). Las primeras son sencillas aberturas en el exterior, estrechas y alargadas, pese a tener cierto abocinamiento por el interior. Los ventanales, aunque son también alargados y estrechos, presentan una mayor complejidad, disponiendo de elementos decorativos diversos. Los óculos son ventanas de forma circular.

- El sistema productivo está relacionado con las características de la organización productiva y parte de la distinción entre la tradición constructiva local, representada por la figura del albañil, y la especializada, liderada por la figura del cantero. ${ }^{14} \mathrm{De}$ esta forma, se diferencia el sistema del albañil (45), el del cantero (42) y dos sistemas mixtos en el que participan ambas figuras, uno en el que se utilizan sólo litologías locales (44) y otro en el que también se usan rocas alóctonas (43) y que reflejaría a priori un mayor esplendor de la construcción y una capacidad de movilización de recurso más elevada por parte de los promotores.

- Los materiales se refieren únicamente a los litologías empleadas para la sillería y las piezas escultóricas, ya que en las iglesias de la Diócesis de Vitoria los mampuestos proceden siempre del entorno local de la construcción (Martínez-Torres 2003: 185; MartínezTorres 2004: 47; Martínez-Torres 2007: 865). Esta variable contiene seis opciones: caliza paleocena ${ }^{15}$

\footnotetext{
14 Ambos conceptos divergen en el material empleado, su tratamiento y su puesta en obra. Así, la tradición especializada implica, por un lado, una elevada capacidad de movilización de recursos por parte de los promotores de la obra, ya que se sustenta en la producción de bloques ortogonales procedentes ex professo de una cantera. Por otro, supone una división del trabajo diversificada con un ciclo de la piedra muy elaborado, esto es, con un gran número de operaciones realizadas por diferentes individuos. La puesta en obra de los bloques es, asimismo, ordenada y predecible. Finalmente, exige la disposición de conocimientos técnicos complejos sobre el trabajo de la piedra. Todo esto desaparece o se simplifica en las producciones de tradición local, cuya dirección no es asumida ya por canteros, sino por albañiles. En ellas no es necesaria una gran inversión o conocimientos técnicos de importancia y apenas hay división del trabajo, puesto que su ciclo productivo se reduce a dos fases: obtención del material y puesta en obra, proceso en el que hay además una mayor libertad (Bianchi 1995; Mannoni 1997: 15, 21; Quirós 2001: 81-282; Quirós 2007: 45).

15 También conocida como "piedra blanca" o "piedra franca alavesa", fue la más demandada para la talla y construcción monumental en Álava debido a su gran calidad, llegando también a ser empleada por canteros y escultores foráneos, principalmente a lo largo del Camino de Santiago. Dispone de unas equilibradas propiedades de labrabilidad y dureza y su textura y color permiten en las tallas estilizar el relieve y realzar los volúmenes (MartínezTorres 2004: 51-52; Martínez-Torres 2009a: 11-14).
}

(14); arenisca albiense ${ }^{16}(15)$; arenisca miocena ${ }^{17}$ (16); calizas del Cretácico Superior ${ }^{18}$ (17); travertino $^{19}(18)$; $\operatorname{aragonito}^{20}(19)$.

- Los instrumentos de talla aluden a aquellos útiles empleados por los canteros sólo para la talla final de los bloques, al ser la operación de labra que tiene lugar en último lugar y, por ello, la más fácilmente reconocible. No obstante, la presencia de marcas de talla depende en buena medida de las litologías empleadas. Mientras que en las rocas duras como la arenisca albiense rara vez se han identificado, en aquellas más aptas para la labra, como la caliza paleocena o la arenisca miocena, son mucho más comunes. Las opciones que tiene en cuenta esta variable son cuatro. El tallante (37), útil de percusión directa (también conocido como escoda), fue el principal instrumento empleado para la talla final en las iglesias románicas, acotándose su uso entre el siglo XI y mediados del siglo XIII (Bessac 1986: 51 y 104; Sánchez Zufiaurre 2007: 328-341). La gradina (40) es el útil dentado de percusión indirecta que sustituirá en preeminencia al tallante en el siglo XIII y hasta mediados del siglo XVI (Bessac 1986: 142 y 185). El trinchante (39) es un útil de percusión directa, como el tallante, pero dentado, como la gradina. Según J. C. Bessac, que lo denomina "bretture", ${ }^{21}$ habría aparecido algo antes que la gradina, a finales del siglo XII, empleándose de forma paralela a ésta hasta el final de la Edad Media (Bessac 1986: 51 y 67). El parecido de las marcas del trinchante y la gradina, que en ocasiones dificultan la propia adscripción a

\footnotetext{
16 Litología de enorme dureza, usada incluso para afilar herramientas, y difícil talla cuyas canteras se hallan en el norte de Álava (Martínez-Torres 2004: 50).

17 Esta litología se encuentra en afloramientos de la Rioja Alavesa y Treviño y se caracteriza por su escasa dureza. Ello permite que sea la roca que más fácil se trabaja e, igualmente, la que menos durabilidad tiene (MartínezTorres 2004: 50).

18 Roca muy común, de origen local y frecuentemente usada para la mampostería que se caracteriza por una gran compacidad y una densidad algo superior a la de la media de las calizas, debido a la ausencia de poros y laminación interna, así como por su gran resistencia al desgaste y a la meteorización (Martínez-Torres 2004: 49).

19 Conocida como toba en lenguaje coloquial, esta litología se empleaba sobre todo para la construcción de bóvedas, debido a su baja densidad, aunque también ocasionalmente para sillares o piezas escultóricas concretas (Martínez-Torres 2004: 48; Martínez-Torres 2011: 106).

20 Se considera una roca exótica, al aparecer sólo puntualmente en algunos sillares de templos de nuestro entorno, aunque probablemente se obtenía de zonas de extracción cercanas. Es blanda, por lo que su labra es sencilla y si se pule se obtienen resultados llamativos para cualquier construcción (MartínezTorres 2004: 52).

21 L. Martínez Torres lo denomina trinchante (o hacha) dentado en oposición al trinchante liso (nuestro tallante) (Martínez-Torres 2004: 30).
} 
uno u otra, se ve afortunadamente paliado por una horquilla cronología muy semejante. El pico (41), instrumento de percusión directa, se ha utilizado de forma intermitente y genérica desde el año mil hasta nuestros días (Bessac 1986: 104).
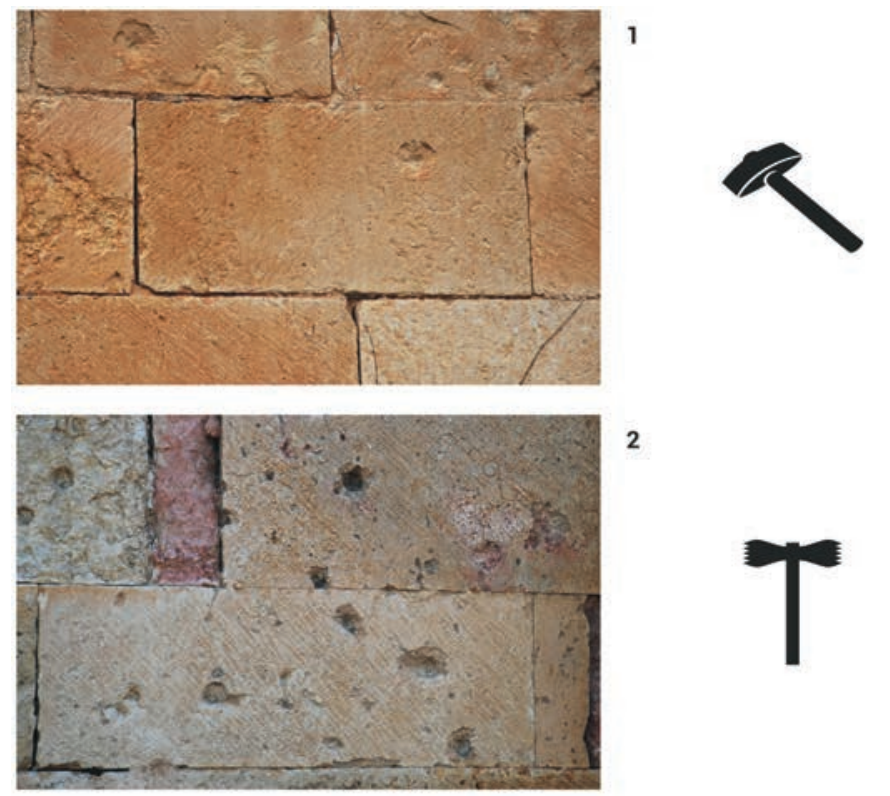

2
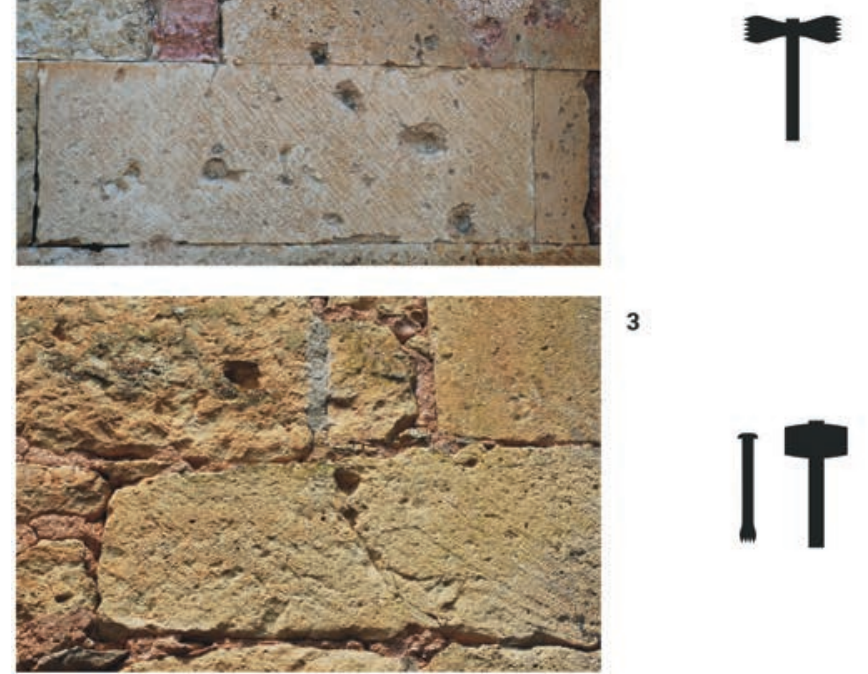

Fig. 3. Marcas de talla: (1) Tallante a $45^{\circ}$ (Moraza, Condado de Treviño); (2) Trinchante (San Vicentejo, Condado de Treviño); (3) Gradina (Corro, Valdegovía).

- Los patrones decorativos se tendrán en cuenta cuando se hallen en impostas, arquivoltas, canes y capiteles. Comprenden 12 opciones, repartidas entre la decoración geométrica y de temática vegetal: ajedrezado (54), círculos (55), encestado (56), sogueado (57), hojas de acanto con la parte superior doblada (58), clavos (59), hojas lanceoladas (60), taqueado simple (61), flores en aspa (62), semiesferas (63) y motivos vegetales organizados en círculos entrelazados (65).

- Dentro de otras variables constructivas se incluyen todos aquellos aspectos que podría ser interesante tener en cuenta para rastrear las capacidades de los constructores y promotores de la obra: la presencia de contrafuertes (53), fragmentos de cornisa decorados (46), de canes decorados ${ }^{22}(47)$, de un marco de sillería (48) o de tímpano (50) en la portada o de elementos decorativos adicionales, como arcos ciegos, semicolumnas o impostas (49). También si la portada se ubica en una posición distinta a la oriental acostumbrada, como al oeste (51) o al norte (52).

\section{Delimitación en periodos. Las marcas de talla como guía preliminar}

Relacionar todas estas variables para definir grupos constructivos homogéneos es una tarea complicada, y más con una muestra de iglesias tan elevada. Las aparentes correlaciones no están exentas de excepciones y resulta arduo definir con claridad los rasgos característicos de cada conjunto. A estas dificultades hay que añadir que trabajamos sobre un lapso cronológico de dos siglos en el que se solaparon diversas soluciones edilicias cuya fijación temporal, sin embargo, no es posible determinar debido a la casi total ausencia de cronologías absolutas. Salvo que cuenten con lápidas fundacionales conservadas o que hayan sido objeto de excavaciones arqueológicas, desconocemos en qué momento preciso se edificaron estas iglesias.

Por todo ello, en una primera aproximación se decidió utilizar como guía principal de ordenación la única variable ${ }^{23}$ con la que, gracias a las obras de J. C. Bessac, era posible obtener cronologías precisas: los instrumentos de talla. Como se ha comentado previamente, el empleo del tallante se extendió entre el siglo XI y mediados del siglo XIII, cuando fue sustituido por la gradina, que se convirtió en el útil predominante hasta la segunda mitad del siglo XVI. El trinchante, por su parte, apareció a finales del siglo XII y su uso se alargó hasta las postrimerías del siglo XV (Bessac 1986: 51, 67, 104, 142 y 185). Vemos, pues, que durante los siglos XII y XIII convivieron tres instrumentos de talla diferentes con cronologías diversas que podrían orientarnos en la tarea de agrupar las fases constructivas de la muestra.

\footnotetext{
22 No se tendrán en cuenta, por tanto, los canes lisos (cuarto de paralelepípedo con interior cilíndrico hueco), así como los de cuarto de esfera, con chaflán o en ángulo recto.

23 Si bien es cierto que en sus trabajos L. Martínez-Torres se refiere a cambios diacrónicos en el uso de las litologías constructivas, éstos son demasiado amplios y no permiten afinar las cronologías con el detalle necesario en este estudio. Según este autor durante el periodo románico y gótico (siglos X-XV) se preferían calizas paleocenas, en el Renacimiento y el Barroco (siglos XVI$\mathrm{XVII}$ ) areniscas albienses y en los siglos siguientes areniscas miocenas. Estos cambios en la roca más demandada los explica a partir de las limitaciones de extracción de cada una, más que en criterios de facilidad de labra o alterabilidad (Martínez-Torres 2004: 57-58; 2007: 864 y 2009b: 42 y 44).
} 


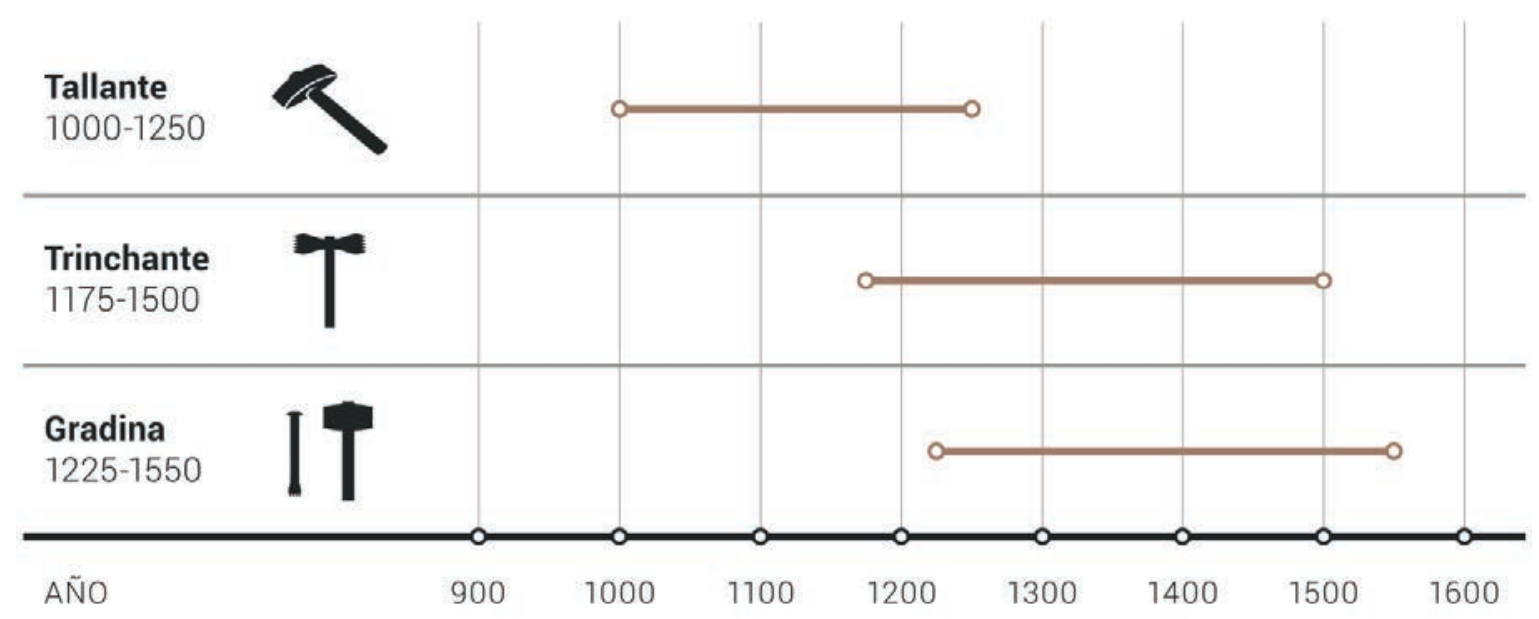

Fig. 4. Cronología aproximada de uso del tallante, el trinchante y la gradina. Fuente: elaboración propia a partir de Bessac 1986.

Sin embargo, antes de continuar conviene cotejar las cronologías absolutas de algunas iglesias con sus marcas de talla para ponderar hasta qué punto es válida la secuencia propuesta por J. C. Bessac en nuestro ámbito geográfico. Tres de las ermitas de la muestra conservan inscripciones que remiten a su fundación, pese a que dos de ellas están en posición secundaria. La primera, San Juan Bautista en Markinez es la única que se conserva in situ y está datada en $1226^{24} \mathrm{y}$ en sus sillares se aprecia el uso mayoritario del tallante (en el ábside, el presbiterio y buena parte de la nave) pero también de la gradina (en la nave y los canes del ábside).

La segunda inscripción, de La Concepción en San Vicentejo (Treviño), tiene una fecha discutida, 1162 (era de 1200), ${ }^{25}$ que algunos historiadores ven posible (Castiñeiras

${ }^{24}$ La lápida dice así: "HEDIFICATIO : HUIUS : TEMPLI : FUIT : FACTA : SUB : ANNO : D : OMNI : M : CC : XX : VI : NONO : KL : DECEMBRIS : IOHE : PETRI : EPO : EXISTENTE : IN : CALAGURRA : ET : REGNANTE : FERDINADO : REGE : IN : CASTELLA : ET : M : ARCHIDIACONO : IN : ARMENTIA : ET : FURTUNIO : DE : MARQUINIZ : ARCHIPRESBITERO : IN : TRIVINIO : ET : GARSIAS : DE : PANGUA : MAGISTRO : IN : ARMENTIA : UT : VIDENTES : HOC : SCRIPTUM : ORENT : PRO : ANIMA : EPI : ESPECIALITER : ET : OMNIBUS : BENEFACTORIBUS : HUIUS : TEPLI "(Portilla y Eguía 1968: 127-128). "Este templo se edificó el día noveno de la calenda del mes de diciembre del año del Señor de 1226, siendo Juan Pedro obispo en Calahorra y reinando Fernando en Castilla y siendo M(artín) arcediano en Armentia y Fortunio de Marquínez arcipreste en Treviño y García de Pangua maestro en Armentia. Para los que vean esta inscripción rueguen especialmente por el alma del obispo y por todos los benefactores de este templo" (Gómez Gómez 1997: 253 , nota al pie $\left.\mathrm{n}^{\circ} 30\right)$.

${ }_{25}$ “++ I(n) N(omin)ED(omin)I N(ost)RI IH(es)V X(rist)I EDIFICATVM EST HOC TEMPLVM IN (h)ONORE(M)S(anc)TI VICENCII ERA MILESIMA CC". "En nombre de Nuestro Señor Jesucristo fue edificado este templo en honor de San Vicente en la era de 1200" (Castiñeiras 2012: 237).
2012: 237) pero que otros consideran errónea. Según estos autores dicha inscripción estaría incompleta, al faltarle algunos trazos, por lo que su cronología sería posterior, de comienzos del siglo XIII (Portilla y Eguía 1968: 190; Ocón 1996: 74). Sus sillares muestran el empleo de tallante y trinchante.

El tercer epígrafe fue hallado en la restauración llevada a cabo en 1975 de la ermita de San Juan Bautista de Karkamu (Valdegovía), en un sillar oculto en el muro interno, bajo la ventana del ábside. Está fechado en $1150^{26}$ y los sillares y piezas líticas del templo reflejan una talla final exclusiva a tallante.

Existe una cuarta lápida de una iglesia que no está en la muestra pero en la que debemos hacer un alto. La ermita y antigua parroquia de San Juan Bautista de Treviño dispone de un epígrafe en posición secundaria que hace referencia a su fundación en 1251 (Portilla y Eguía 1968: 217-218). En la iglesia, asimismo, se emplea tanto tallante como gradina, con una ligera preeminencia de la segunda, principalmente en los paramentos superiores del ábside. La combinación de ambas tallas alcanza tal punto que uno de los sillares exteriores del torreón semicircular al norte tiene la mitad de su cara vista trabajada con tallante y la otra mitad con gradina, sin que se aprecien procesos posteriores de retallado.

\footnotetext{
26 En ella se lee: "AN CEI L CISTER VENIT". "Anno centesimo quinquagesimo cister venit” (García Guinea y Pérez González 2011: 902). Una fecha que para A. Gómez, no obstante, resulta extraña, por ser temprana, todavía en vida de San Bernardo, para la orden del Cister en la península (Gómez Gómez 2000: 132).
} 

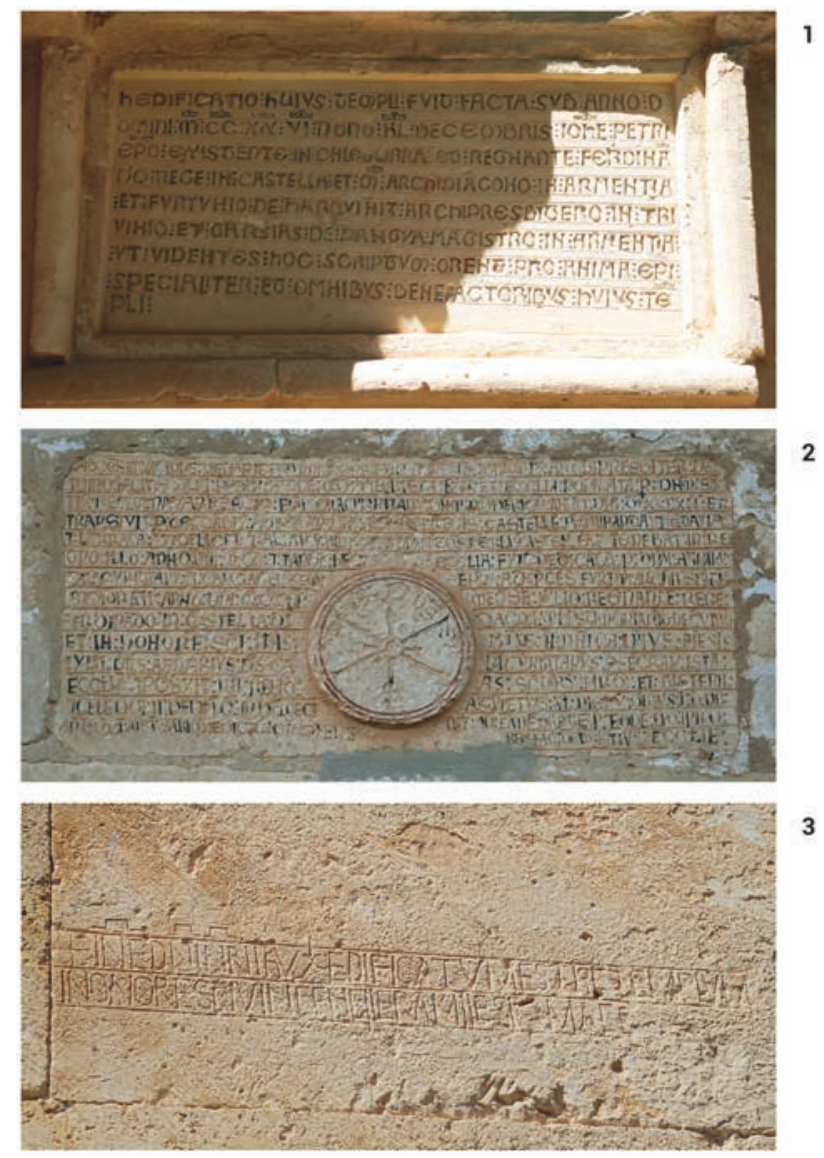

Fig. 5. Tres de las inscripciones fundacionales referidas: (1) San Juan Bautista (Markinez); (2) San Juan Bautista (Treviño); (3) La Concepción (San Vicentejo).

Resultan útiles a este respecto los resultados de las excavaciones arqueológicas en iglesias, ya que aportan indicadores que permiten vincular los instrumentos de labra con cronologías concretas. Así, tanto las piezas de caliza paleocena en posición secundaria halladas junto al templo de Santa María erigido en la primera mitad del siglo XII en el despoblado de Zornoztegi (Salvatierra) como los paramentos in situ de San Prudencio de Armentia (Vitoria-Gasteiz) o San Román de Tobillas (Valdegovía), sugieren una clara relación entre la arquitectura eclesial de este siglo y el empleo del tallante (Quirós 2008; Lasagabaster et al. 2006; Azkarate 1995).

Estos ejemplos permiten, en definitiva, concluir una serie de cuestiones sobre el empleo del tallante, el trinchante y la gradina durante los siglos XII y XIII. En primer lugar, parece confirmarse la horquilla cronológica ofrecida por J. C. Bessac para el tallante. Tanto los ejemplos referidos de iglesias excavadas, como su uso en la ermita de San Juan Bautista de Karkamu (1150) y Treviño (1251), así lo confirman.
Por otro lado, la gradina está documentada desde 1226, así que sabemos que ya se empleaba en nuestro territorio como mínimo en esta fecha. Ello no contradice necesariamente lo dicho por el arqueólogo francés, que consideraba dudoso el uso de la gradina para la primera mitad del siglo XIII por los pocos casos en los que se había identificado (Bessac 1986: 185).

En tercer lugar, queda la duda, debido a los problemas de transcripción de la lápida de San Vicentejo, de si realmente el empleo del trinchante puede adelantarse a una fecha tan temprana como $1162 .{ }^{27}$ Con todo, e independientemente de la fecha en que se erigió dicha iglesia, parece plausible afirmar que el empleo del trinchante se adelantó en el tiempo al de la gradina.

En cualquier caso, estos problemas de delimitación temporal del trinchante, su coincidencia cronológica, aunque adelantándose quizá unas décadas, con la gradina, las ocasionales dificultades, ya referidas, para diferenciar las marcas de ambos útiles y las diferencias cuantitativas y cualitativas entre la muestra de iglesias de uno frente a la de la otra ${ }^{28}$ nos han permitido aunar ambos instrumentos y diferenciar tres grandes periodos en la edificación de iglesias de los siglos XII y XIII: fases constructivas con tallante ( $c a$. 1100-1250), fases con útiles dentados ( $c a$. 1220-1300) y fases con tallante y útiles dentados ( $c a .1220-1250)$.

\section{Delimitación en periodos. Distribución definitiva}

Siguiendo el criterio anterior se han definido tres periodos: el periodo 1 , el más antiguo y correspondiente a las fases constructivas con tallante, queda formado por 45 de las 112 de la muestra; el periodo 2, tallante y útiles dentados, integra 11; y el periodo 3 , útiles dentados, 23. No ha sido posible atribuir a ninguno de estos tres periodos 33 fases constructivas de los siglos XII-XIII $(29,5 \%$ de la muestra) puesto que sus paramentos no evidenciaron el empleo de ninguno de estos útiles. Un porcentaje importante que trataremos de reducir a lo largo de los siguientes párrafos.

Para ello se hará uso de un instrumento común del que debe valerse la arqueología de la arquitectura, junto

\footnotetext{
27 Cabe mencionar, en cualquier caso, que J. C. Bessac consideró factible que ya en el tercer cuarto del siglo XII se pudiera haber usado este útil (Bessac 1986: 104).

28 Se han identificado 17 sólo con gradina y cuatro únicamente con evidencias de trinchante.
} 


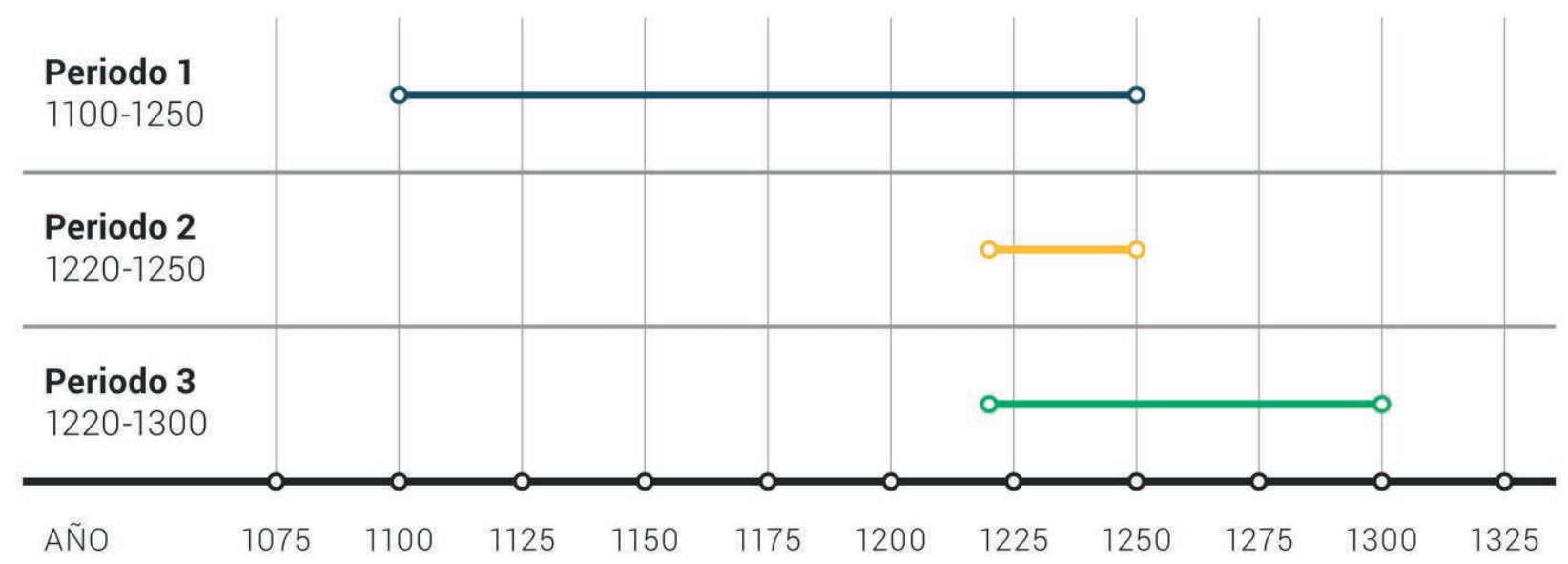

Fig. 6. Cronología de los tres periodos diferenciados.

a la estratigrafía, la arqueometría o la propia estratigrafía (Quirós 2002: 28-29): los estudios histórico-artísticos, basados en las analogías formales de elementos. Hace más de dos décadas G. P. Brogiolo defendía así la necesidad de este tipo de análisis para la naciente disciplina:

Un edificio no está constituido sólo por estratos, sino también por formas. La lectura estratigráfica, al limitarse a documentar y secuenciar las acciones constructivas, no posee los instrumentos conceptuales que definen los aspectos estilísticos y formales de un edificio. [...] Los conocimientos histórico-artísticos son también indispensables para establecer la equivalencia entre distintas acciones constructivas (Brogiolo 1995: 32).

Resulta fundamental, con todo, que estos estudios se desarrollen siempre una vez se haya desarrollado la secuencia estratigráfica. ${ }^{29}$ De esta forma, "una vez documentado en contextos estratigráficos, el estilo de ciertos elementos constructivos y ornamentales también constituye una variable tipológica capaz de ofrecer cronologías de notable precisión para espacios culturalmente acotados" (Moreno 2014: 10).

El primero de estos análisis se centrará en las seis iglesias del noroeste de Álava próximas entre sí cuyos vanos comparten destacables características. Se trata de

\footnotetext{
29 "Stratigraphy provides a route to understanding of the elaborate constructional and decorative sequences that will be the basis for developing new and accurate typologies. Related to these, parallels emerging from traditional typologies do not work any longer, because they have to consider the building as a whole, and as having several constructions. Parallels thus become more complex and difficult to establish, as far as they depend on the stratigraphic sequence" (Utrero 2010: 25).
}

las parroquias de Katadiano, Zuhatzu-Kuartango (en Kuartango), Beluntza, Oiardo (en Urkabustaiz), Guillerna (en Zuia) y Olano (en Zigoitia). Forman un área triangular de unos $80 \mathrm{~km}^{2}$, cuyo vértice norte estaría en Oiardo, el este en Olano y el sur en Zuhatzu-Kuartango.

Al menos uno de los vanos de cada uno de estos templos se corresponde con un ventanal ornamentado elaborado con piezas talladas en diferentes litologías (salvo en el caso de Guillerna, donde sólo se empleó la arenisca albiense). En ellos tanto la disposición (con trasdós, arquivoltas, imposta y tres columnas) como los motivos decorativos, se repiten de forma llamativa.

Asimismo, y salvo la mencionada excepción de Guillerna, todos estos ventanales se ejecutaron empleando litologías variadas. En tres de los casos se alternaron piezas de caliza paleocena, arenisca albiense y calizas del Cretácico Superior (Zuhatzu-Kuartango, Katadiano y Beluntza) y en los otros dos se combinaron estas últimas con calizas paleocenas (Oiardo) y areniscas albienses (Olano). Este fenómeno, que hallamos en otros templos de los ayuntamientos de Kuartango y Urkabustaiz, implica una elevada planificación y un amplio conocimiento de las características de cada roca por parte de los canteros, que debían ocuparse de preseleccionar las piedras, transportarlas desde canteras dispersas y subrayar las cualidades de cada una, fundamentalmente cromáticas, en el conjunto (Martínez-Torres 2011: 108-109).

Las composiciones litológicas complejas y las similitudes decorativas apuntadas sugieren que las seis iglesias se edificaron en un lapso de tiempo breve y muy probablemente a manos del mismo taller constructivo. Dado que la fase de la parroquia de Beluntza está ubicada dentro del periodo 3 (ca. 1220-1300), al 


\begin{tabular}{|c|c|c|c|c|c|c|}
\hline & BELUNTZA & GUILLERNA & KATADIANO & OIARDO & OLANO & $\begin{array}{l}\text { ZUHATZU- } \\
\text { KUARTANGO }\end{array}$ \\
\hline AJEDREZADO & Arquivoltas & - & Impostas & - & Arquivoltas & - \\
\hline $\begin{array}{r}\text { BOLAS } \\
\text { (¿TEMA VEGETAL?) }\end{array}$ & Capiteles & Capiteles & - & Capiteles & Capiteles & Capiteles \\
\hline círculos & $\begin{array}{l}\text { Arquivoltas } \\
\text { Impostas } \\
\text { Trasdoses }\end{array}$ & - & Arquivoltas & - & - & Arquivoltas \\
\hline ENCESTADO & Arquivoltas & Arquivoltas & - & - & - & - \\
\hline $\begin{array}{r}\text { HOJAS } \\
\text { DE ACANTO }\end{array}$ & Arquivoltas & - & Arquivoltas & - & - & Arquivoltas \\
\hline $\begin{array}{r}\text { HOJAS } \\
\text { LANCEOLADAS }\end{array}$ & $\begin{array}{l}\text { Impostas } \\
\text { Trasdoses }\end{array}$ & Trasdoses & - & Impostas & - & - \\
\hline $\begin{array}{l}\text { ROSTROS } \\
\text { HUMANOS }\end{array}$ & - & - & Capiteles & - & Capiteles & Capiteles \\
\hline SOGUEADO & Arquivoltas & Arquivoltas & Arquivoltas & Arquivoltas & Arquivoltas & Arquivoltas \\
\hline
\end{tabular}

Fig. 7. Relación de motivos decorativos en los vanos de las seis iglesias del noroeste alavés.

contar con marcas de gradina, podemos adscribir sin excesivos obstáculos el resto de templos a este mismo momento.

El segundo de estos acercamientos histórico-artísticos hará referencia a las cuatro iglesias en Kuartango (el antiguo edificio parroquial de Archua y las parroquias de Sendadiano, Tortura y Urbina Eza) que disponen de un tipo de portada muy similar y poco común en la arquitectura de nuestro territorio en los siglos XII-XIII: cuatro arquivoltas apuntadas (tres en el caso de Archua) que apoyan sobre jambas de arista, con imposta y trasdós. Todo ello ejecutado mediante el empleo de calizas del Cretácico Superior y sin un solo elemento decorado. Esta misma morfología de portada (con tres arquivoltas) hallamos en la ermita de San Pedro de Gorostiza, en Zestafe (Zigoitia), al norte de la provincia, aunque en arenisca albiense.

La similitud de estas portadas con la de la parroquia de Arenaza (Arraia-Maeztu), a pesar de situarse en el otro extremo de la provincia y de estar realizada con calizas del Paleoceno, es indiscutible. Su vano de acceso, que cuenta con las tres arquivoltas de Archua y la ermita de San Pedro, muestra idéntica sobriedad y disposición. Por ello es posible que, de nuevo, nos hallemos ante un mismo taller constructivo que trabajó en varias iglesias del territorio o, al menos, ante una preferencia para la que presuponemos cierta coincidencia cronológica. Así pues, esta similitud tipológica nos posibilita adscribir las fases de los cuatro templos cuartangueses y la er-
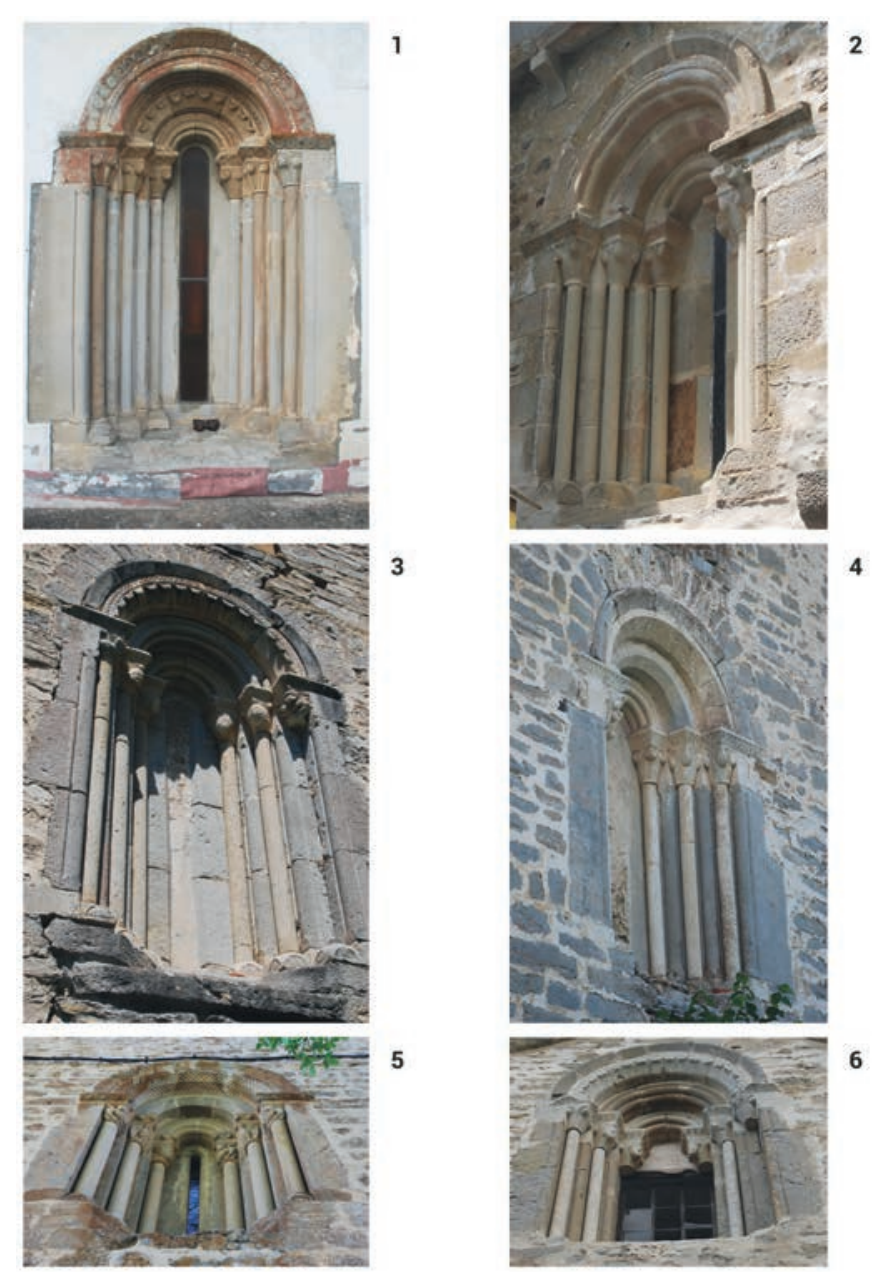

Fig. 8. Ventanales semejantes de Beluntza (1), Guillerna (2), Katadiano (3), Oiardo (4), Olano (5) y Zuhatzu-Kuartango (6). 
mita en el periodo 3 ( $c a$. 1220-1300), donde, debido a las evidencias del uso de gradina en la propia portada, habíamos incluido la fase de Arenaza.
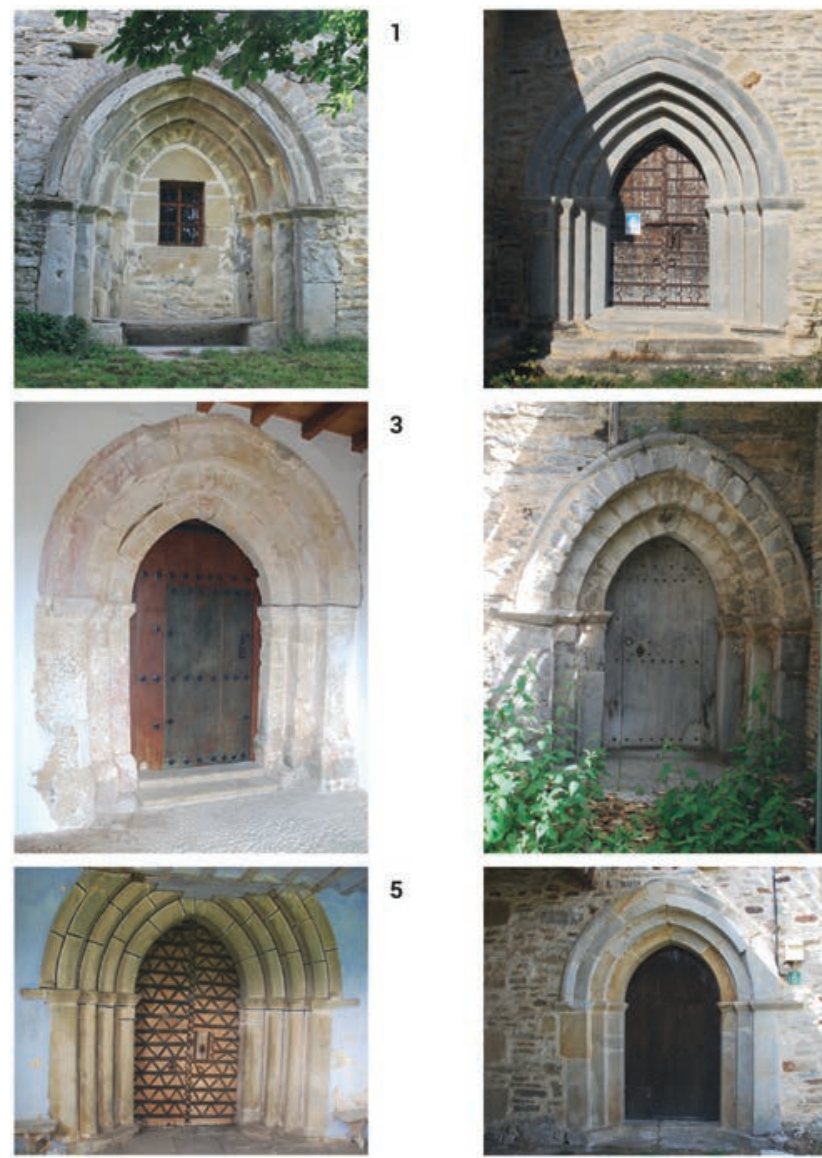

3

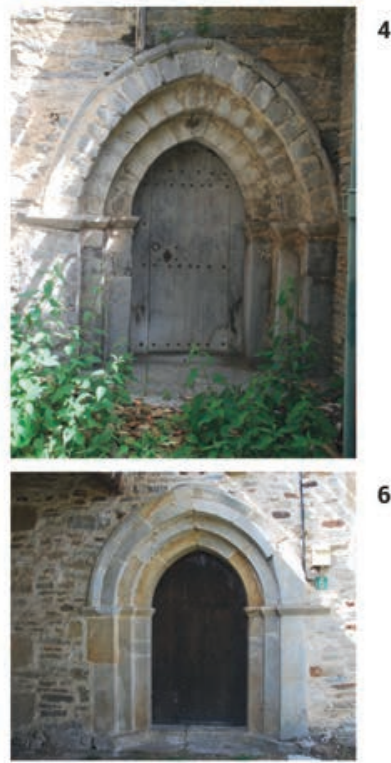

Fig. 9. Portadas semejantes de Sendadiano (1), Tortura (2), Arenaza (3), Artxua (4), Urbina Eza (5) y San Pedro de Gorostiza (6).

En tercer lugar, el ábside semicircular en sillería de la ermita de Nuestra Señora de Elizmendi, en Kontrasta (Valle de Arana), parece tener poco que ver con las elaboradas cabeceras de esta morfología que hallamos en otras iglesias de la muestra.

Sus reducidas dimensiones, ${ }^{30}$ la presencia de una única saetera en el ábside a modo de iluminación y de excepcionales modillones circulares sin cornisa en su remate o que se planificase una cubierta de madera y no una bóveda de horno podrían sugerir una mayor antigüedad o los "tanteos de una fase creativa temprana" (López de Ocáriz 2014: 40-41). Estas peculiares características y

\footnotetext{
30 El análisis de las dimensiones de los presbiterios en las iglesias de cabecera semicircular en Álava y Treviño revela que las de esta ermita son excepcionalmente reducidas. La medida A (anchura del presbiterio) es de 2,1 $\mathrm{m}$, la B (longitud del presbiterio) de 2,2 $\mathrm{m}$ y su área útil de 4,6 $\mathrm{m}^{2}$, mientras que las medias excluyendo este templo alcanzan los $4,6 \mathrm{~m}$ para la medida $\mathrm{A}$, los 2,6 m para la B y los $12,1 \mathrm{~m}^{2}$ para el área útil.
}

el hecho de que, como veremos más adelante, las iglesias con ábside semicircular se concentran en el periodo 1 (ca. 1100-1250) nos impelen a ubicar aquí, y quizá en un momento inicial del periodo, esta ermita.

Por último, el remate de los muros de la nave de la ermita de San Julián y Santa Basilisa (Zalduondo), sin cornisa y con grandes canes decorados, recuerda más al de la ermita de Nuestra Señora de Elizmendi que al típico de la arquitectura "románica" por lo que podría ser reflejo de su antigüedad. Por ello, y a pesar de que las intervenciones arqueológicas no han ofrecido hasta la fecha una cronología precisa de dicha reforma, consideramos que esta fase debe integrarse también en el periodo 1 ( $c a .1100-1250)$.

En definitiva, y a partir de la argumentación expuesta, se habría conseguido reducir la cantidad de individuos sin clasificar de 33 a 21, a un más razonable 18,8 $\%$, quedando la distribución definitiva entre periodos de la siguiente manera: periodo 1, 47 fases; periodo 2, 11 fases; periodo 3, 33 fases.

\section{Tendencias}

Tras llevar a cabo esta distribución ya podemos analizar con más detalle las variables de los individuos para subrayar así los contrastes en las formas de edificar iglesias de los tres periodos. Con todo, asumimos que, salvo excepciones concretas, ninguno de los periodos será totalmente homogéneo o dispondrá de rasgos diferenciales únicos. Las transformaciones edilicias en estos dos siglos deberán ser rastreadas a partir de alteraciones destacadas en los porcentajes de cada una de las opciones.

Hay que tener en cuenta que la mayoría de las variables analizadas no deberían contar con un significado diacrónico claro, respondiendo más a otros factores funcionales, sociales o productivos (Ferrando et al. 1989: 654), por lo que no hay que tomar todas en consideración, “...sino sólo aquellas que tengan un valor lo suficientemente representativo como para ser consideradas como marcadores cronológicos" (Vargas 2013: 13). De esta forma, se reconocen hasta cuatro variables con alteraciones tan significativas entre los periodos 1 y 3 como para poder atribuirles un sentido diacrónico.

En primer lugar, el sistema productivo de cantería se reduce considerablemente en el periodo 3 respecto al $1 \mathrm{y}$ al 2. Esto es, a lo largo del siglo XIII se generalizan las iglesias con sistema mixto en cuya construcción el cantero tiene un menor protagonismo, limitándose sólo al remate, los vanos y, de forma ocasional, los esquinales. 


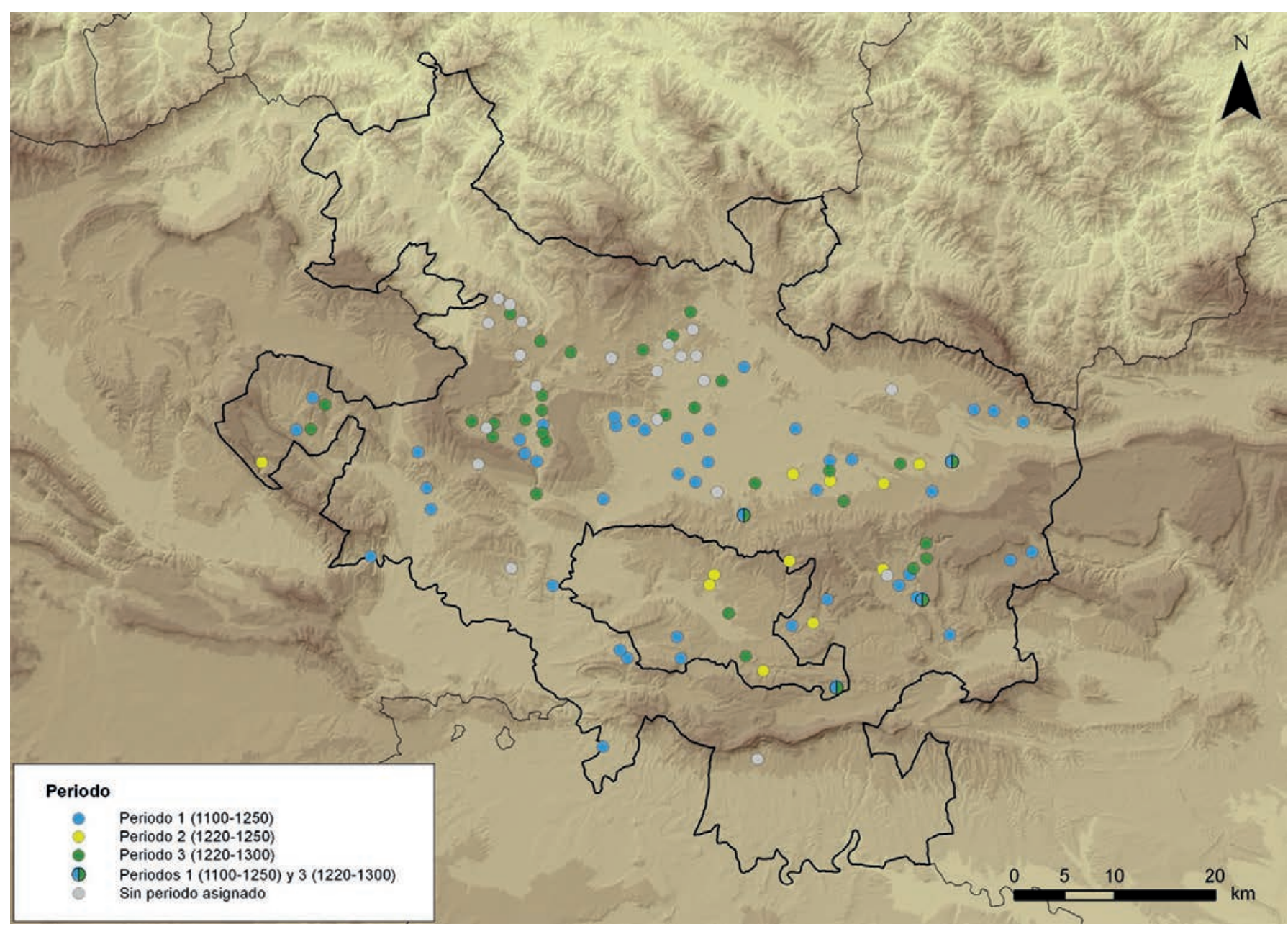

Fig. 10. Mapa con la distribución de las iglesias de los tres periodos diferenciados (Autor: J. Ordoño).

Mientras que en los periodos 1 y 2 más del $40 \%$ de las fases están erigidas sólo por canteros $(42,6 \%, 20$ de 47, en el primero y $45,5 \%, 5$ de 11 , en el segundo), en el periodo 3 dicho porcentaje se reduce hasta el 15,2\% (5 de 33).

También en la morfología del ábside se identifican destacables cambios. En el periodo 1 los ábsides rectos están prácticamente igual de representados que los semicirculares, 48,7 \% (19 de 39) y 46,2 \% (18 de 39) respectivamente, siendo los ochavados muy minoritarios $(5,1 \%$, 2 de 39). Aunque en una muestra mucho más reducida, y por tanto más tendente a error, parece que esta proporción se reduce en el periodo 2 , siendo el 54,6\% ábsides rectos (6 de 11), el 36,4\% semicirculares (4 de 11) y el 9,1\% (1 de 11) ochavados. En cualquier caso, esta tendencia se verá acentuada en el periodo 3, donde prácticamente los templos de ábside semicircular desaparecen. De los 25

\footnotetext{
31 Cuando, como en este caso, la muestra específica para esta variable no corresponda con la muestra total del periodo, significa que no se han tenido en cuenta los casos en los que no se haya conservado el objeto de análisis (ábsides, portadas o vanos orientales).
}

templos que componen la muestra 23 tienen ábside recto $(92 \%)$, uno semicircular ${ }^{32}$ y otro ochavado (ambos $4 \%$ ).

Otra de las tendencias de cambio sobre la que debemos hacer un alto corresponde a la tipología de los vanos en la fachada oriental. Aunque en los tres periodos los ventanales tienen un predominio manifiesto sobre las saeteras, parece observarse un descenso del uso de éstas últimas en los periodos 2 y 3 . En este sentido y durante

\footnotetext{
32 El único ejemplar de ábside semicircular en el periodo 3 corresponde a la parroquia de San Juan Evangelista en Acebedo (Valdegovía). El templo ha sido adscrito a este periodo por las marcas de gradina que se observan en algunas piezas del remate pero lo cierto es que nos es imposible aseverar con una mínima seguridad que la cornisa y los canes fueran realmente elaborados en los siglos XII-XIII. Las modificaciones a las que ha sido sometido el templo en épocas posteriores resultan evidentes por la ausencia de vano oriental, puesto que todas las iglesias medievales, y hasta la extensión de los retablos en el siglo XVI, contaban con uno o más vanos abiertos hacia el este. Sin embargo, estas reformas son difícilmente identificables por el enlucido que cubre sus muros de materiales no trabajados. Este hecho, junto a la propia morfología de la portada, que parece asociarse más con el periodo 1 (véase más adelante), hacen sospechar que la iglesia quizá fuera edificada en un momento anterior.
} 


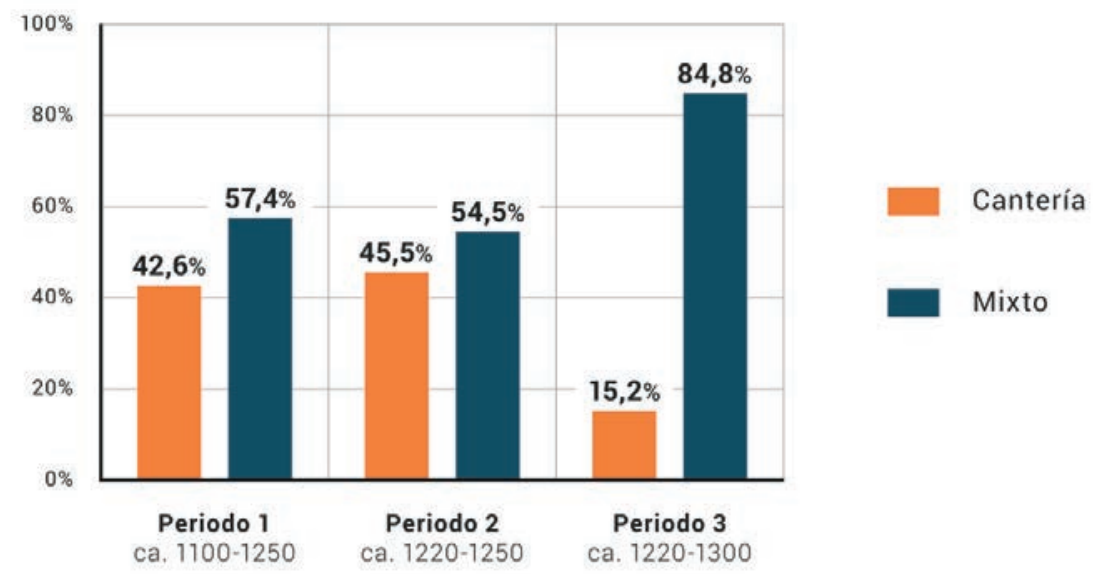

Fig. 11. Representación porcentual de los sistemas productivos mixto y de cantería por periodo.

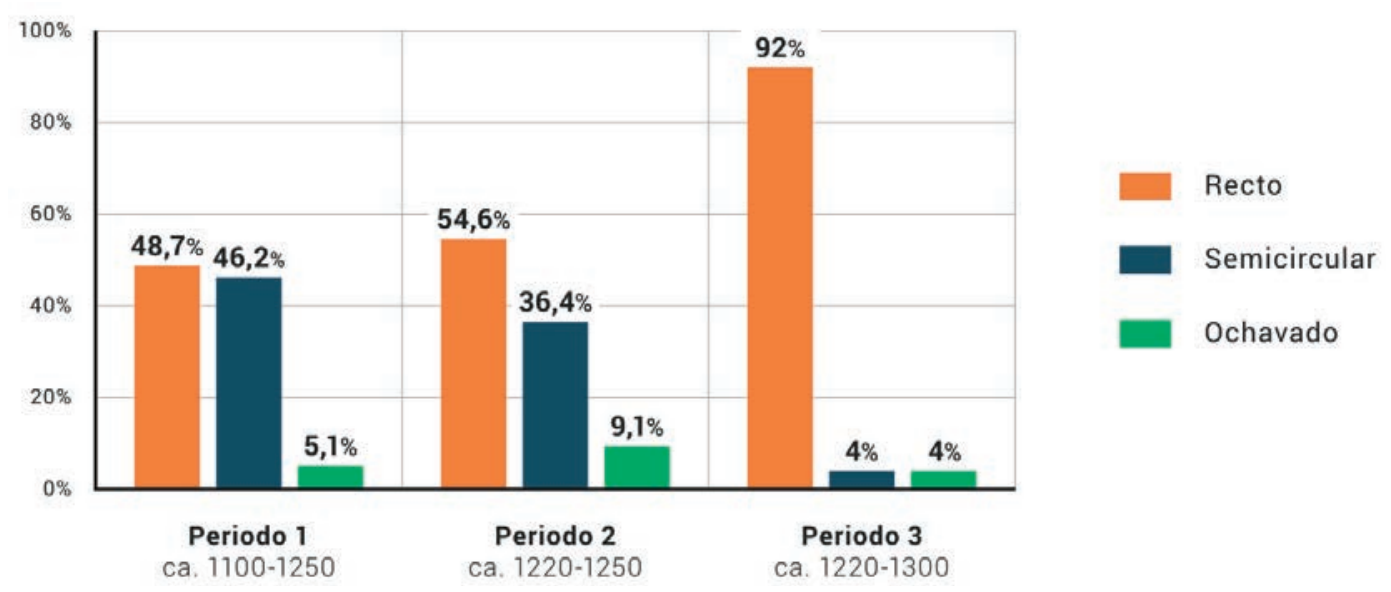

Fig. 12. Representación porcentual de ábsides rectos, semicirculares y ochavados por periodo.

el periodo 1, la presencia de ventanales en el muro de cierre oriental corresponde al $71,4 \%$ de la muestra ( 25 de 35 ), la de saeteras al $22,9 \%$ ( 8 de 35 ) y la de saeterasventanales y óculos-ventanales al $2,9 \%$ cada una ( 1 de 35). En el periodo 2 el porcentaje de saeteras se reduce al 9,1 \% (1 de 11), mientras que aumenta el de ventanales $(81,8 \%, 9$ de 11$)$ y saeteras-ventanales $(9,1 \%, 1$ de 11), produciéndose escasos cambios en dichos porcentajes $^{33}$ durante el periodo 3. Estos datos sugieren una clara preferencia, según se avance en estos dos siglos, hacia vanos más elaborados, costosos y con mayores posibilidades de ornamentación que las ventanas monolíticas o las sencillas saeteras.

Por último, haremos referencia a los cambios en el empleo de aquellas litologías utilizadas para la ejecución

\footnotetext{
$3373,7 \%$ de ventanales (14 de 19); 10,5\% de saeteras (2 de 19), así como de saeteras-ventanales; $5,3 \%$ de óculos (1 de 19).
}

de sillares, sillarejos y piezas talladas, generalmente traídos de canteras alejadas pero que ocasionalmente tenían un origen local. ${ }^{34}$

Si analizamos los datos en bruto, sin tener en consideración para qué se empleaban estas litologías o si su uso era generalizado o puntual (obras de cantería u obras mixtas), no se aprecian diferencias destacables entre los tres periodos. El empleo de calizas paleocenas es mayoritario o exclusivo. En el periodo 1 el 40,4\% (19 de 47) de las fases emplean exclusivamente este tipo de roca, mientras que el 53,2\% (25 de 47) lo hace en combinación con otros. Sólo en el 6,4 \% (3 de 47) de los casos no se atestigua su uso. En el periodo 2 la caliza paleocena aparece en sus once fases: en siete

\footnotetext{
34 Ello ocurre con las parroquias de Leorza, Musitu (Arraia-Maeztu) y San Miguel (Ribera Alta), construidas íntegramente con rocas de calidad, incluyendo la mampostería, debido a afloramientos locales. En concreto, las dos primeras emplean calizas paleocenas y la tercera areniscas miocenas.
} 


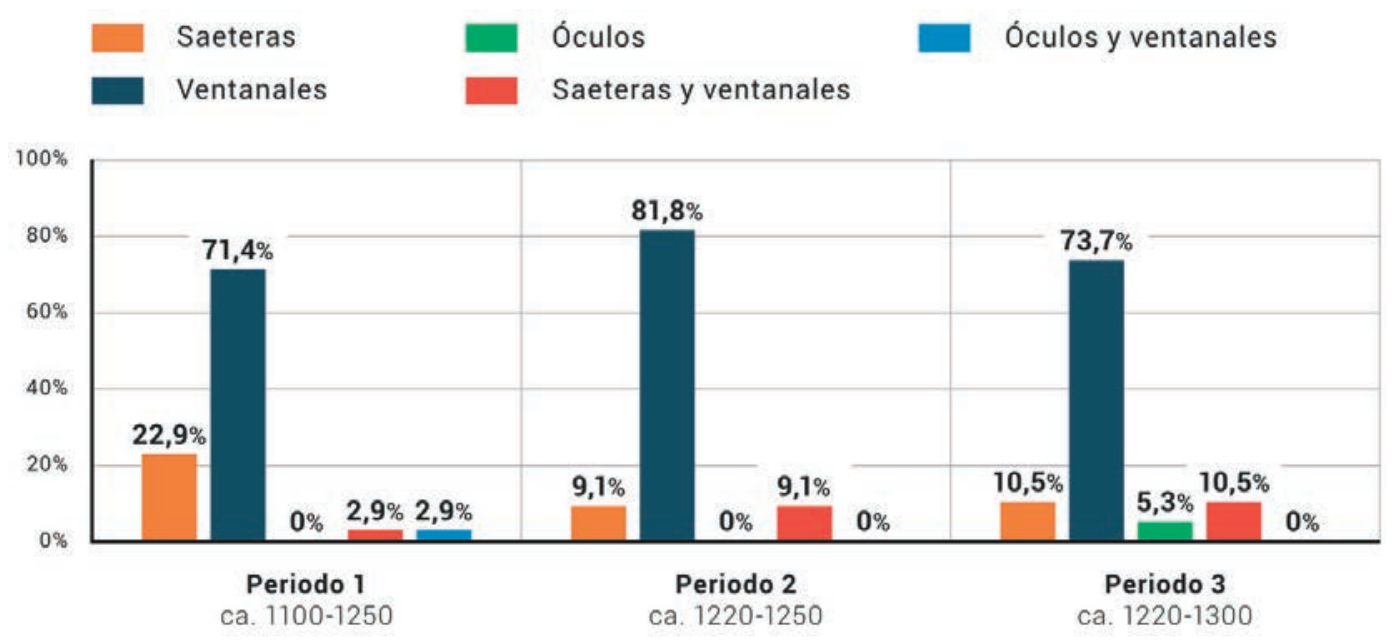

Fig. 13. Representación porcentual de los tipos de vanos en la fachada oriental por periodo.

de forma exclusiva $(63,6 \%)$ y en las cuatro restantes combinada (36,4\%). El periodo 3 muestra una utilización semejante de este material, representando un $84 \%$ de la muestra total $(45,4 \%, 15$ de 33 , solo y $39,4 \%, 13$ de 33, combinado).

Resulta significativo que sea en las fases sin periodo asignado donde se encuentra el menor porcentaje de empleo de calizas paleocenas, apareciendo de forma exclusiva en el $10 \%(2 \text { de } 20)^{35}$ de los casos. Ello se explica sin duda porque las marcas de talla, guía de la

35 No se ha contabilizado la ermita de Nuestra Señora de Goikogana (Oiardo) por ser la única ejecutada bajo un sistema productivo de albañilería, al menos a tenor de los restos conservados. distribución en periodos, se identifican mejor en las calizas paleocenas que en el resto de litologías.

No obstante, si ceñimos el análisis a las fases con sistema productivo mixto, aquéllas en las que se limitó el empleo de rocas de calidad a elementos puntuales, se observan cambios relevantes entre el periodo 1 y 3 . Parece que, mientras que en el periodo 1 la caliza paleocena es claramente el material predominante en las piezas de cantería (esquinales, portada, vanos y remate), en el periodo 3 su demanda se reduce en favor de otros materiales.

Ello se percibe perfectamente al comparar los datos sobre los esquinales. En el periodo 1 los esquinales de sillería y sillarejo y en litologías de calidad representan
Caliza paleocena de forma exclusiva
Caliza paleocena combinada con otras litologías
Otras litologias

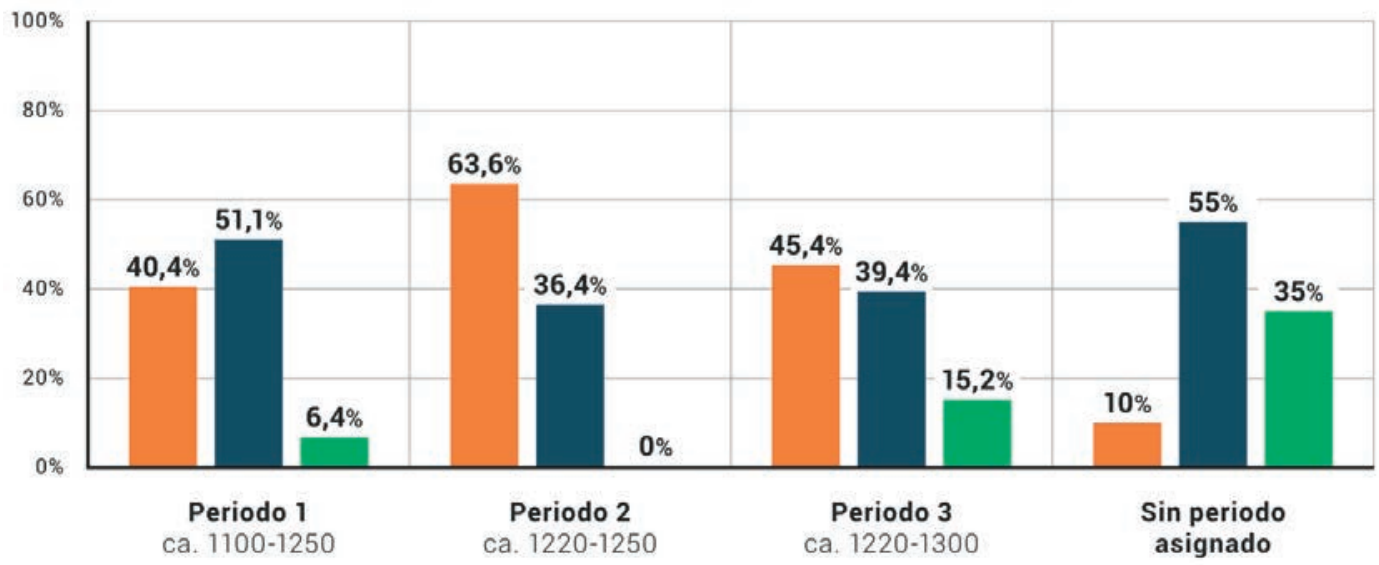

Fig. 14. Representación porcentual de las litologías empleadas en sillares, sillarejos y piezas talladas por periodo. 
el $75 \%$ de la muestra ( 15 de 20$)$, empleándose en un 40 $\%$ de los casos totales ( 8 de 20) la caliza paleocena de forma exclusiva y en un $15 \%$ (3 de 20) combinada con otra roca. En el periodo 3, por el contrario, los esquinales de sillería y sillarejo con estas litologías se reducen a un $25 \%$ ( 7 de 28 ), ejecutándose un $14,3 \%$ de la muestra total (4 de 28) con caliza paleocena, de forma exclusiva $(10,7 \%, 3$ de 28$)$ o combinada $(3,6 \%, 1$ de 28$)$. Parece, por tanto, que en este momento las iglesias que optan por emplear en sus esquinales sillares y sillarejos en materiales de calidad son una clara minoría, prefiriendo otras litologías locales que podían ser trabajadas y puestas en obra por albañiles a un menor coste.

Esta misma reducción en el empleo de la caliza paleocena, aunque menos acusada, se identifica al analizar la evolución de las portadas, vanos y remates (canes y cornisas). Mientras que en el periodo 1 el $95 \%$ (19 de 20) de las portadas se han elaborado con caliza paleocena, el $80 \%$ (16 de 20) empleándola de forma exclusiva, en el periodo 3 esos porcentajes se reducen al $66,7 \%$ (12 de 18$)$ y $55,6 \%$ (10 de 18$)$ respectivamente.

Del mismo modo, en el 87,5\% (21 de 24) de los casos del periodo 1 se ejecutaron vanos con caliza paleocena, en el 66,7 \% (16 de 24) sin combinarla con ninguna otra roca. En el periodo 3, sin embargo, dichos porcentajes caen al 76,2 \% (16 de 21) y $42,9 \%$ (9 de 21$)$.

Los materiales empleados para los canes y cornisa del remate reflejan idéntico proceso. Siendo en el periodo 1 los remates realizados sólo en caliza paleocena los más demandados $(52,4 \%, 11$ de 21$)$ y apareciendo esta litología en el 76,2 \% de los casos (16 de 21), en el periodo 3 estas cifras disminuyen considerablemente. El $30,4 \%$ de los remates de este periodo ( 7 de 23 ) fueron realizados exclusivamente con caliza paleocena, empleándose esta roca en el 47,8\% (11 de 23) de los casos.

El resto de variables analizadas no presentan diferencias tan marcadas entre periodos. Así, tanto en el periodo 1 como en el 3 se identifican las cuatro opciones discriminadas para la morfología de la portada: arquivoltas-columnas, arquivoltas-baquetones, arquivoltas-jambas de arista y arco-jambas de arista. Sin embargo, sus porcentajes muestran una cierta tendencia a la homogeneización que no puede ser pasada por alto. Mientras que en el periodo 1 son dos opciones las predominantes (arquivoltas-columnas y arquivoltas-jambas de arista), con valores por encima del $30 \%(39,3 \%$ y $32,1 \%$ respectivamente), ${ }^{36}$ en el periodo 3 la morfología arquivoltas-jambas de arista despunta con claridad, ocupando casi la mitad de la muestra $(47,6 \%, 10$ de $21)$, sobre la de arquivoltas-columnas $(28,6 \%, 6$ de 21$)$, arquivoltas-baquetones (19\%, 4 de 21$)$ y arco-jambas de arista, prácticamente desaparecida, con un único $\operatorname{caso}^{37}(4,8 \%)$.

Variaciones más sutiles entre los periodos 1 y 3 se evidencian también en las opciones tenidas en cuenta en "Otras variables constructivas". En este sentido, los

\footnotetext{
36 Le siguen más lejos las portadas con arquivoltas-baquetones y arcojambas de arista (ambas 14,3\%, 4 de 28).

37 Éste corresponde a la referida parroquia de Acebedo. Como comentábamos más arriba, la presencia tanto de esta portada, más típica del periodo 1 (aunque minoritaria), como del propio ábside semicircular, pueden sugerir una cronología más temprana a la establecida.
}

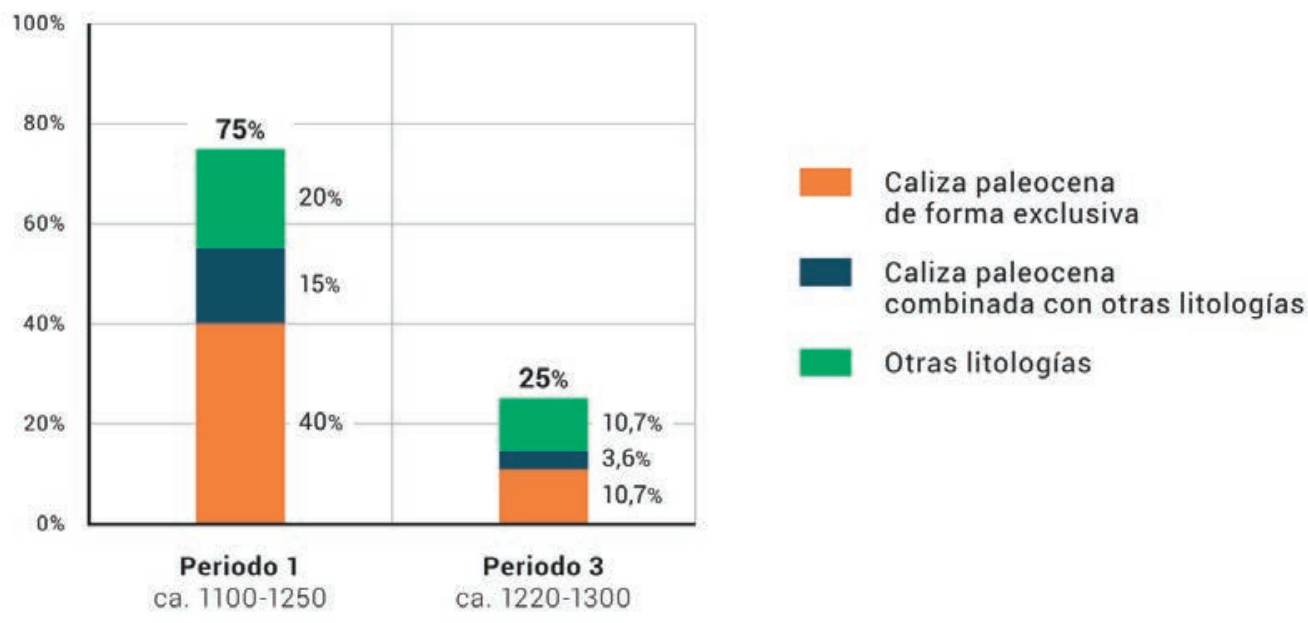

Fig. 15. Representación porcentual por periodo de las litologías empleadas en los esquinales de las iglesias con sistema productivo mixto. 


\section{Portadas}

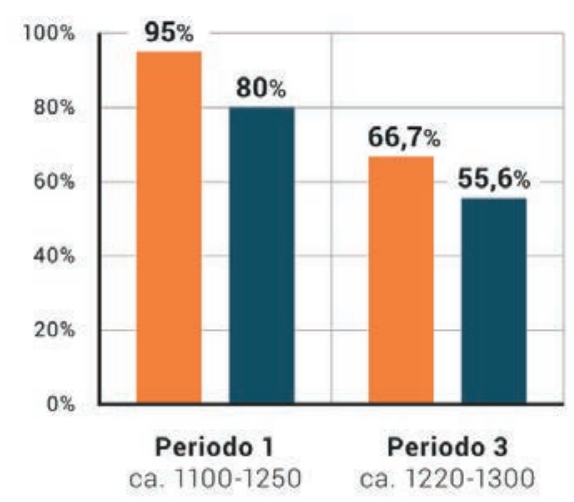

TOTAL caliza paleocena

Caliza paleocena de forma exclusiva

Vanos

Remates
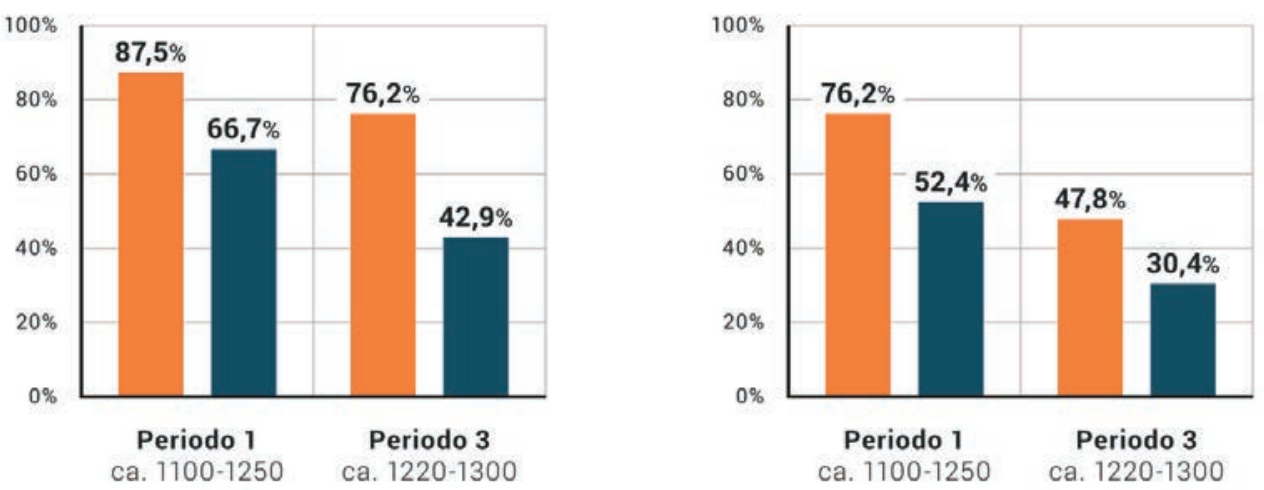

Fig. 16. Representación porcentual por periodo de las litologías empleadas en portadas, vanos y remates de las iglesias con sistema productivo mixto.

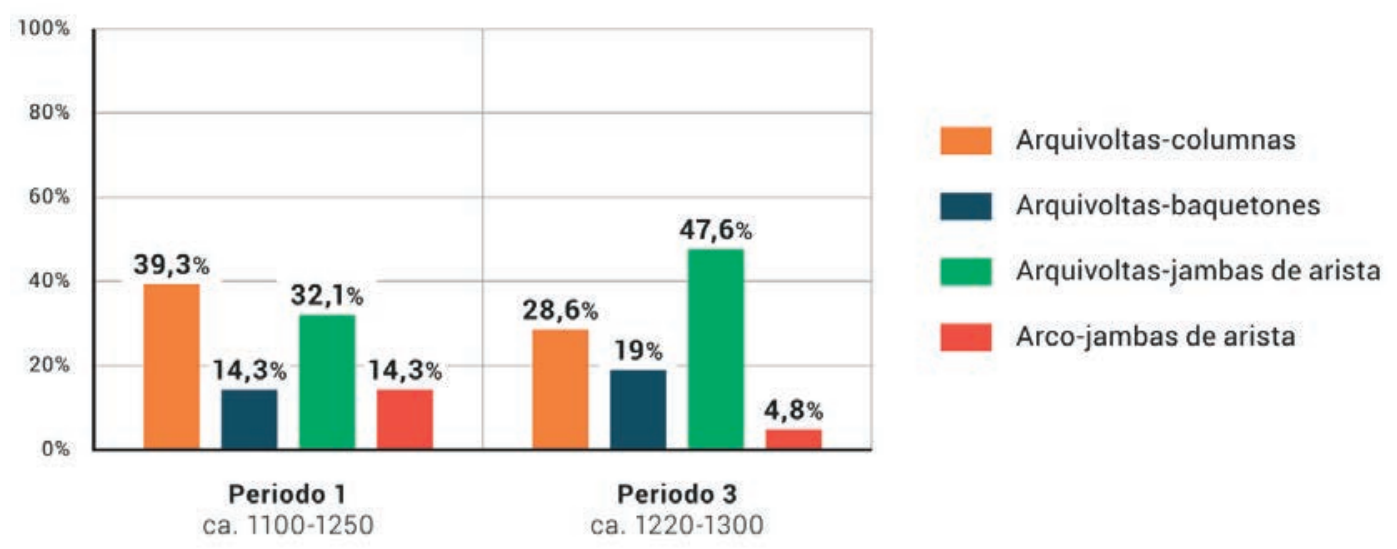

Fig. 17. Representación porcentual de los tipos de portada por periodo.

canes decorados son mayoritarios en el 1 respecto al 3. De las 42 fases en las que los hallamos el 57,1\% (24) pertenecen al periodo 1 y el $21,4 \%$ (9) al periodo $3 . .^{38}$

\footnotetext{
38 Faltan los dos casos del periodo $2(4,8 \%)$ y los siete sin periodo asignado $(16,7 \%)$.
}

Lo mismo ocurre con las cornisas decoradas: mientras que del periodo 1 son el $61,5 \%$ ( 8 de 13$)$, del periodo 3 únicamente el $15,4 \%$ (2 de 13$).{ }^{39}$

\footnotetext{
39 Faltan los dos casos del periodo $2(15,4 \%)$ y la fase sin periodo asignado $(7,7 \%)$
} 
Igualmente, los elementos decorativos adicionales (semicolumnas, impostas o arcos ciegos) que ornamentaban algunos ábsides durante el periodo 1 no pervivieron más allá del periodo 2 , probablemente por su relación con las morfologías semicirculares y ochavadas, que prácticamente desaparecen en este momento. Los porcentajes son claros: el $66,7 \%$ de las fases con estos elementos se adscriben al periodo 1 ( 8 de 12) y el 33,3 $\%$ al periodo 2 (4 de 12 ).

Con todo, el resto de opciones de esta variable no parece reflejar grandes desigualdades entre periodos. Los contrafuertes, ${ }^{40}$ tímpanos $^{41}$ o marcos de sillería rodeando la portada ${ }^{42}$ aparecen representados de forma homogénea en los tres periodos. Por otro lado, los tres casos en que la portada se emplazó al oeste (las parroquias de Jokano, Sendadiano y Tortura) parecen responder a una tendencia concreta del valle de Kuartango que sobrepasa nuestra periodización..$^{43} \mathrm{El}$ único caso en que se situó al norte, la ermita de San Martín de Lantarón en Sobrón, se debió probablemente a la orografía, ya que la parte sur daba a un desfiladero y la norte al camino de acceso a la antigua aldea.

Tampoco la preferencia por un patrón decorativo parece estar relacionada directamente con un periodo específico, aunque sí que ciertos motivos tienen más presencia en unos que en otros. Ello ocurre con el ajedrezado ${ }^{44}$ y las semiesferas, ${ }^{45}$ representados de

\footnotetext{
40 Periodo 1: 4. Periodo 2: 2. Periodo 3: 3. Sin clasificar: 1.

41 Periodo 2: 1. Periodo 3: 1.

42 Periodo 1: 5. Periodo 2: 5. Periodo 3: 6. Sin clasificar: 1.

43 Periodo 1: 1. Periodo 3: 2.

44 Periodo 1: 23. Periodo 2: 3. Periodo 3: 10. Sin clasificar: 3.

45 Periodo 1: 10. Periodo 3: 2. Sin clasificar: 4.
}

forma mayoritaria en el periodo $1(59 \%$ y $63 \%$ respectivamente). El resto de patrones tiene una muestra demasiado limitada o está lo suficientemente repartido para ser tomado en consideración. ${ }^{46}$

\section{CONCLUSIONES}

Como se puede observar, algunas de las variables constructivas codificadas en la muestra tienen un evidente valor diacrónico, ya que se circunscriben mayoritariamente a un periodo concreto. Ello no significa, sin embargo, que cualquiera de estos caracteres pueda actuar como marcador cronológico único, al no producirse una correspondencia completa entre variable y periodo.

En las siguientes líneas se tratará, por tanto, de inferir las implicaciones de esta diacronía, tratando de comprender las transformaciones que se produjeron en los siglos XII-XIII no sólo en la arquitectura eclesiástica o en la organización productiva de los constructores, sino en las propias sociedades locales y en los poderes que actuaban en su seno.

Dos son las conclusiones principales, y complementarias, que extraemos de los datos presentados. Por un lado, que durante el periodo 3 (ca. 1220-1300) se edificaron templos con una menor participación de

\footnotetext{
46 El caso de las hojas lanceoladas es significativo. Cuatro de las cinco fases en las que se identificó este motivo (las parroquias de Beluntza, Miñano Menor, Oiardo y Olano) pertenecen al periodo 3, siendo la quinta la parroquia de Ondategi, sin periodo asignado. Si la muestra hubiese sido mayor $\mathrm{y}$, en consecuencia, la correlación entre este patrón decorativo y el periodo 3 hubiese estado más fundamentada, se habría considerado la adscripción de la fase de Ondategi al mismo.
}

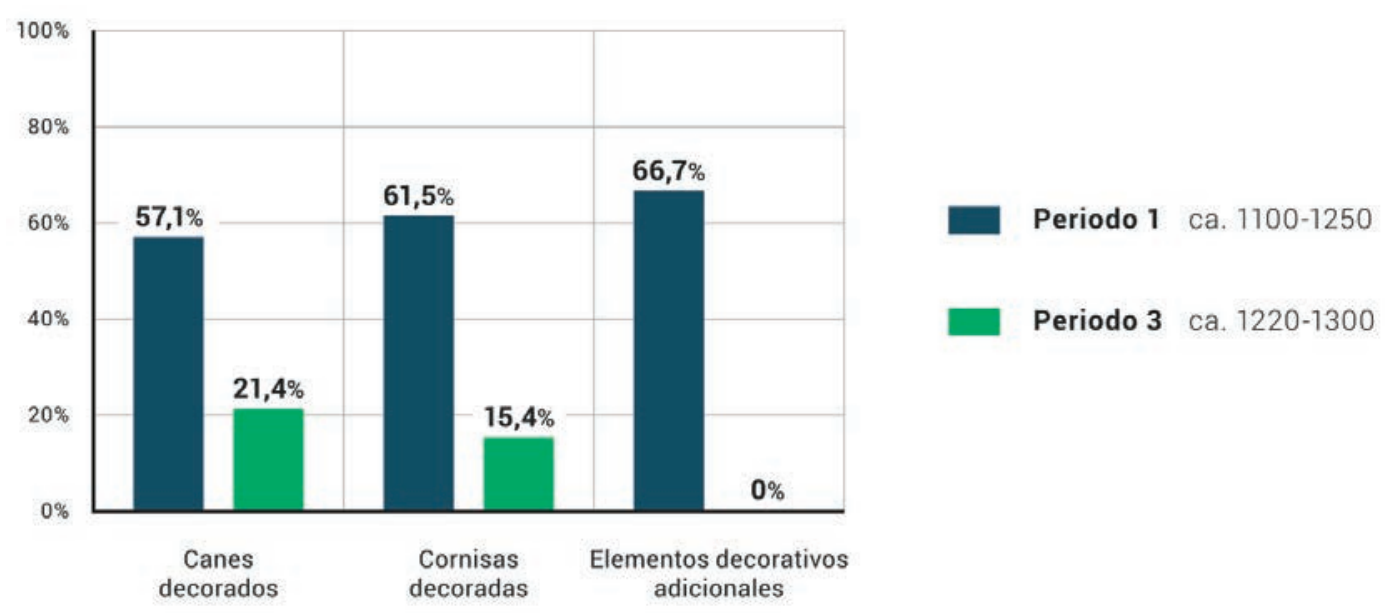

Fig. 18. Representación porcentual de la presencia de canes decorados, cornisas decoradas y elementos decorativos adicionales en los periodos 1 y 3 . 
canteros, de menor complejidad técnica y menos costosos que en el periodo 1 ( $c a$. 1100-1250). Por otro, que en el periodo 1 coexistieron una mayor variedad de soluciones arquitectónicas que se redujeron considerablemente en el 3, tendiendo a una cierta homogeneidad. Ambas conclusiones muestran la existencia de profundos cambios tanto en las estructuras productivas de la mano de obra como en la entidad y capacidad de los promotores.

\section{Iglesias más asequibles, rápidas de erigir y técnicamente menos complejas}

La primera de las conclusiones la argumentamos a partir de las siguientes cuatro tendencias apuntadas más arriba. En primer lugar, los templos construidos con un sistema productivo de cantería se reducen de forma considerable en el periodo 3 (de superar el 40 $\%$ a un $15 \%$ ), en favor de las edificaciones mixtas en las que colaboraban albañiles y canteros. Estas últimas tenían, evidentemente, un coste bastante menor. Por un lado, sus paños estaban realizados con mampostería local de diverso tratamiento y no con sillería nueva de cantera traída desde lugares más o menos alejados. La calidad del material, su transporte y su talla en perfectos paralelepípedos terminaban por encarecer mucho la obra. Por otro lado, la mayor parte de las operaciones del proceso constructivo estaban en manos de los albañiles, peor remunerados que los canteros por sus menores conocimientos técnicos.

Este tipo de construcción mixta, en la que los canteros se limitaban a ejecutar los vanos, el remate y, a veces, los esquinales de los muros, permitía además una construcción mucho más rápida que bajo el sistema de cantería. Al fin y al cabo, para edificar los muros no había que esperar a traer el material desde alejadas canteras, dedicar varias horas a su labra o colocar cuidadosamente cada bloque. El ciclo de la piedra era mucho más simple y se reducía a la obtención del material y la puesta en obra, como mucho ejecutando un somero tratamiento de las piezas entre ambas operaciones.

En segundo lugar, prácticamente dejan de erigirse iglesias con ábsides semicirculares en el periodo 3, cuando casi habían representado el $50 \%$ de la muestra en el 1. Las cabeceras de esta morfología eran mucho más exigentes que las rectas en el plano técnico. Después de todo, cerrar un edificio con una estructura semicircular implicaba conocimientos avanzados de arquitectura que no estaban al alcance de cualquiera, sobre todo si se pretendía cubrirla con una bóveda de horno. El ábside recto, por el contrario, suponía un simple cierre perpendicular idéntico a los del resto del templo y no demandaba una cubierta pétrea específica. Por todo ello, en la mayoría de los casos, siempre que no se eligieran cubiertas complejas con el ábside recto, optar por un ábside semicircular aumentaba los costes e, irremediablemente, ralentizaba la obra.

Podría argumentarse que la preferencia por uno $\mathrm{u}$ otro tipo de ábside respondió a las capacidades técnicas de cada cuadrilla itinerante de canteros o a preferencias arquitectónicas del momento. A fin de cuentas, el ábside semicircular se considera un elemento típico del estilo románico en toda Europa occidental (López de Ocáriz y Martínez de Salinas 1988: 42). Es posible que en el siglo XIII los talleres constructivos ya no ejecutasen este tipo de cabeceras o que sencillamente dejara de demandarse, por lo que apenas la encontramos en el periodo 3. O por una combinación de ambos factores. En cualquier caso, aún admitiendo el valor de estos razonamientos, consideramos que la realidad debió responder a una causalidad más variada. No debemos obviar la disparidad técnica y de coste entre un tipo de ábside y el otro, así como la tendencia general en el periodo 3 a erigir iglesias menos costosas y elaboradas.

En tercer lugar, el descenso del número de cornisas y canes ornamentados en el periodo 3. La labra de motivos decorativos en estos remates implicaba, después de todo, un aumento de los costes. Lo mismo se puede decir de las semicolumnas, impostas y arcos ciegos que decoraban algunos ábsides semicirculares y ochavados en los periodos 1 y 2 y que desaparecieron en el 3 .

En cuarto y último lugar, la demanda de caliza paleocena se reduce en el periodo 3 en favor de otros materiales. Hay que tener en cuenta que esta litología es "la reina de todas las rocas de construcción monumental y talla en Álava" precisamente porque tiene un punto medio de labrabilidad y durabilidad, a diferencia de las areniscas albienses y miocenas (Martínez-Torres 2004: 51). Si disminuyó el empleo de esta litología hay que suponer que existió una voluntad tanto de limitar los costes de construcción por parte de los promotores como de trabajar con otro tipo de materiales por parte de la mano de obra. En no pocas ocasiones, de hecho, los materiales no se sustituyeron por otros de calidad semejante, como las areniscas mencionadas, sino por litologías de menor nivel, como las calizas del Cretácico Superior, generalmente usadas para la mampostería. Este hecho, especialmente llamativo en las cornisas 
y canecillos ${ }^{47}$ refleja hasta qué punto se alteraron las preferencias y capacidades de los diversos actores que participaban en el proceso constructivo.

La preferencia por soluciones técnicas menos elaboradas como el ábside recto, por la mampostería frente a la sillería, por materiales de menor calidad o por una menor cantidad de elementos decorados sugiere profundos cambios en la demanda entre el siglo XII y, al menos, la segunda mitad del siglo XIII. Parece evidente que los promotores en el periodo 3 demandan templos menos costosos, probablemente porque muchos de los pudientes poderes anteriores ya habían abandonado esta actividad edilicia y porque las diferencias entre los restantes promotores, sobre todo en lo que a capacidad de movilización de recursos se refiere, se redujeron de forma considerable.

Surge en este punto una pregunta imprescindible: ¿quién está detrás de la construcción de iglesias en el siglo XII y quién lo está en el siglo XIII? Atendiendo a los indicios expuestos, y a la tendencia hacia la homogeneidad del periodo 3 (véase más abajo), resulta factible que durante el periodo 1 coexistieran en estas empresas poderes nobiliares y monasteriales junto a elites y comunidades aldeanas. De tal forma, podemos entender el siglo XII como una etapa de transición entre el tipo de demanda que hundía sus raíces en la Alta Edad Media, compuesta por familias de nobles y monasterios con diversa influencia territorial, y la que vino después a lo largo del siglo XIII y más adelante: las propias comunidades aldeanas que promovieron los templos parroquiales, asociadas (y sometidas) a un poder diocesano cuya colaboración en estas actividades es difícil de cuantificar.

Es razonable pensar que estas comunidades, contando con menos recursos que los tradicionales poderes fundadores, demandasen iglesias más asequibles y que éstas adquirieran relevancia estadística precisamente cuando dichos promotores pasaron a ser mayoritarios.

Por otro lado, y aunque como se ha dicho resulta difícil ponderar la aportación de los obispados en estas actividades edilicias, suponemos que se limitó a destinar el tercio diezmal relativo a la fábrica de cada parroquia ${ }^{48}$ y poco más. Hay que suponer que la diócesis

\footnotetext{
47 Los remates elaborados sólo en calizas del Cretácico Superior, que habían tenido una representación marginal en el periodo 1, pasan a ser más de un cuarto de la muestra en el periodo 3 .

48 La práctica ordinaria en las iglesias episcopales parece haber sido la división en tres tercios: uno para el obispado y el cabildo catedralicio, otro para el clero parroquial y un tercero para la fábrica, esto es, la construcción y mantenimiento de los templos y accesorios (Díaz de Durana y Guinot 2010: 74).
}

estaba inmersa en pleno proceso de construcción de la red parroquia ${ }^{49}$ y debía ocuparse de que cada parroquia contase con un edificio apropiado para el culto y con su mobiliario litúrgico correspondiente. Para ello era necesario reformar las iglesias que habían obtenido de otros poderes, algunas por su estado ruinoso y otras porque debían ser adaptadas a las nuevas funciones parroquiales. Pero también construir templos ex novo en todas aquellas parroquias que no contasen todavía con uno propio. Es probable, pues, que impulsase la entrada en escena de las comunidades aldeanas y permitiese que éstas capitalizasen la financiación de las obras.

No debemos, aún así, limitar el análisis a una diferencia de capacidades económicas entre viejos y nuevos promotores. Es probable que los poderes tradicionales, con dificultades cada vez mayores para mantener sus posesiones eclesiásticas, buscaran emplear estos templos como instrumentos de representación de su menguante poder. Tuvieron, por ende, un genuino interés en invertir más recursos en sus iglesias del que carecieron más adelante las comunidades aldeanas.

Pero vayamos más allá. En el periodo 3 desaparecen la mayor parte de las iglesias señoriales ${ }^{50}$ desvinculándose sus promotores de las actividades ligadas a ellas. De forma paralela, las construcciones de cantería pasan a ser minoritarias. ¿Sería posible correlacionar de alguna manera ambos hechos? Los únicos templos aparentemente asociados a un monasterio de la muestra que se edificaron o, existiendo previamente, se reformaron en los siglos XII-XIII pertenecen al periodo $1 \mathrm{y}$ están realizados bajo un sistema de cantería. Por ello consideramos que dicha relación, sin ser absoluta, pudo existir. En concreto, nos referimos a la ermita de Santa María de Torrentejo (Labastida), mencionada como monasterio en el Becerro Galicano de finales del siglo XII; ${ }^{51}$

\footnotetext{
49 El análisis de la documentación escrita muestra cómo durante la centuria 1150-1250 se produjo en Álava y Treviño la expansión del poder episcopal en un marco de fuerte conflictividad sociopolítica frente a la nobleza y los monasterios, que continuaron controlando buena parte de las iglesias rurales. La segunda mitad del siglo XIII representó, sin embargo, el triunfo definitivo de la autoridad diocesana que acabó controlando, si no todas, buena parte de las iglesias del mundo local, plenamente articuladas dentro de la jerarquía diocesana y que pagaban los impuestos eclesiásticos exigidos (Alfaro 2016: 51-52).

50 Con "iglesia señorial" nos referimos a las ecclesiae y monasteria de la documentación altomedieval, que se caracterizan por su carácter familiar, su organización variable y poco definida y su carácter privado. Sus dueños, que pudieron ser laicos (familias nobiliares o monarquía) o religiosos (monasterios $\mathrm{u}$ órdenes militares), las fundaban con intereses materiales y espirituales y las donaban, compraban y enajenaban como cualquier otra propiedad.

51 “De monasterio Sancte Marie de Torrentelio, iuxta Iberum" Becerro Galicano Digital [doc. 597] (www.ehu.eus/galicano/id597).
} 
la ermita de Nuestra Señora de Elizmendi (Kontrasta), calificada de monasterio en un documento de $1203^{52}$ y la ermita de San Juan Bautista de Karkamu (Valdegovía), cuyo epígrafe en posición secundaria remite a su origen cisterciense (véase más arriba).

Esta vinculación entre las obras de cantería y los viejos promotores no debería sorprendernos demasiado. Al fin y al cabo, las iglesias monasteriales ${ }^{53}$ y señoriales se edificaron con objetivos y funciones muy diferentes a las parroquiales de la diócesis y las comunidades aldeanas. Del mismo modo y como se ha comentado, la capacidad de movilización de recursos de unos y otros era muy desigual, así como su interés en emplear dichas iglesias para representar su poder. No es extraño, por tanto, que sus caracteres constructivos acabasen por ser tan diversos.

\section{Iglesias más homogéneas}

La reducción en el número de soluciones constructivas, que llevó a una mayor homogeneidad en la arquitectura eclesiástica del periodo 3 , se evidencia al combinar tres de las variables diacrónicas identificadas: el sistema productivo, la morfología del ábside y la tipología de los vanos orientales. Así, mientras que las iglesias erigidas con sistema mixto, ábside recto y con ventanales en la fachada oriental no representan en ningún caso el $20 \%$

52 En este texto, procedente del Cartulario de Irache, doña Sancia Pedriz de Uztuniga dona al monasterio de Santa María la Real de Irache las tres partes que tenía en el monasterio de Santa María de Elizmendi (López de Ocáriz 2014: 14-15).

53 Empleamos el concepto "iglesia monasterial" para aludir a la iglesias instaladas dentro del complejo de un monasterio sub regula, no a las iglesias que eran propiedad de un monasterio.

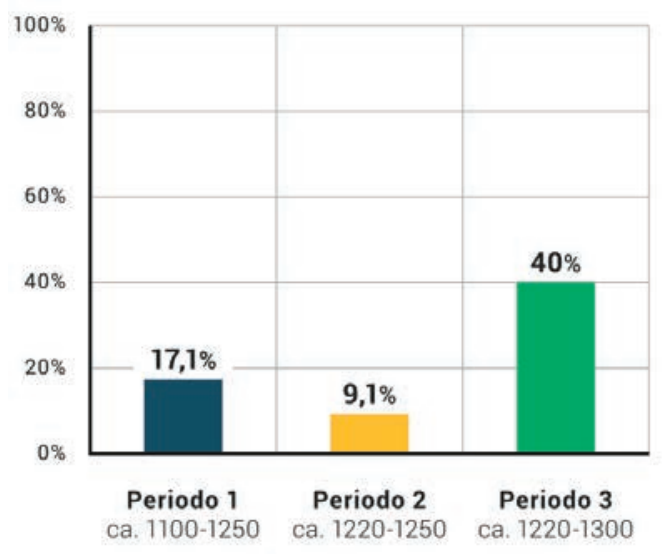

de la muestra en los periodos 1 y $2(17,1 \%, 6$ de 35 , y $9,1 \%, 1$ de 11$)$, dicho porcentaje se dobla en el periodo $3(40 \%, 12$ de 30$)$.

Dicha tendencia a la uniformidad es mucho más evidente si se prescinde de la variable de la tipología de los vanos orientales. De hecho, las iglesias del periodo 1 elaboradas con un sistema productivo mixto y ábside recto representan menos de un tercio de la muestra $(28,2$ $\%, 11$ de 39). Este porcentaje se mantiene durante el periodo $2(27,3 \%, 3$ de 11$)$ pero asciende hasta un significativo $80 \%$ (20 de 25) durante el 3.

Hay que señalar que no todas las tendencias apuntadas más arriba confirman la mayor homogeneidad de las iglesias de este periodo. Así, mientras que en el 1 la caliza paleocena es la litología más empleada para las piezas de cantería, en el 3 su importancia decrece, trabajándose otros materiales hasta entonces menos solicitados. Este hecho, sin embargo, podría ponerse en relación con los nuevos promotores del siglo XIII y su demanda de iglesias menos costosas. Los talleres arquitectónicos, en aras de reducir gastos, optaron quizá por trabajar con materiales más próximos y de menor calidad, ahorrándose el costoso transporte desde las canteras de caliza paleocena.

Con todo, resulta evidente que frente a una mayor variedad de modelos en los edificios de culto del siglo XII se impone en el XIII una iglesia tipo fundamentalmente de mampostería, con ábside recto y, en menor medida, ventanales al este. Ello no significó que desaparecieran las alternativas sino que se convirtieron en opciones minoritarias o marginales. El escenario diverso y heterogéneo del periodo 1 se desvaneció ante el triunfo de ciertas opciones que pasaron a ser mayoritarias en el 3.

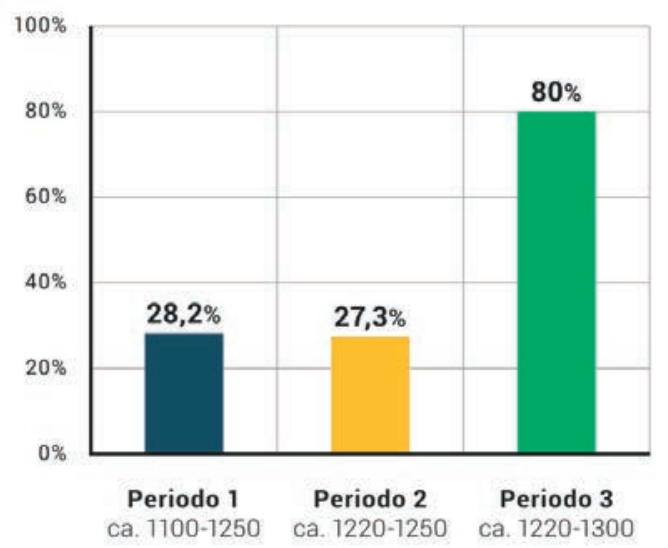

Fig. 19. Representación porcentual por periodo de las iglesias erigidas con sistema mixto, ábside recto y ventanales al E (izquierda) y de las iglesias erigidas con sistema mixto y ábside recto (derecha). 
Si bien una mayor homogeneidad en la arquitectura eclesiástica podría asociarse con el cambio en la naturaleza de los promotores al que aludíamos más arriba, consideramos que está también directamente relacionada con las transformaciones que en el siglo XIII se produjeron en la organización del artesanado en el ámbito de la producción arquitectónica. De un modelo de cuadrillas itinerantes, predominante desde la Alta Edad Media (Caballero y Utrero 2005: 186; Sánchez Zufiaurre 2007: 230-236), se pasó a otro cimentado en talleres locales radicados por todo el territorio. Si el primero se caracteriza por su gran variedad de soluciones arquitectónicas, al contar con mano de obra especializada que trabajaban los materiales in situ, ocupándose de todas las etapas del ciclo productivo, el segundo se distingue precisamente por lo contrario. La creación de talleres estables permitió una mayor especialización en cada operación y, en consecuencia, el desarrollo de una manufactura en serie.

Estas transformaciones están irremisiblemente unidas a una estabilización de la demanda que debió producirse a lo largo del siglo XIII. Se solicitaron más edificaciones de calidad y ello hizo rentable la creación de estos centros de producción en serie con trabajadores especializados que se ocupaban de todas las operaciones que comprendía la actividad edilicia en sus tres ciclos productivos: piedra, madera y cal.

Es probable que dichos talleres actuaran localmente, cubriendo la demanda de regiones no demasiado grandes. Ello parecen sugerir las seis iglesias parroquiales del periodo 3, señaladas más arriba por sus semejanzas formales, que se extienden en una zona de apenas $80 \mathrm{~km}^{2}$ en el noroeste de la provincia. Su proximidad geográfica, el empleo de un sistema mixto, su ábside recto y, sobre todo, la semejanza tipológica y decorativa de sus ventanales orientales parecen reflejar la actividad de un mismo centro productor radicado en esta zona.

Así pues y a tenor de lo expuesto, es necesario matizar la propuesta que L. Sánchez Zufiaurre realiza en su tesis doctoral y por la que este cambio en la organización de la producción arquitectónica en Álava, de cuadrillas a talleres, se habría producido con el románico, debido a la homogeneidad de sus soluciones constructivas (Sánchez Zufiaurre 2007: 343-344). Los datos ofrecidos sugieren que todavía en el siglo XII predominaban las cuadrillas itinerantes y que fue a partir de la siguiente centuria cuando se impusieron los talleres de ámbito local.

En definitiva, el siglo XII fue para la arquitectura eclesial en Álava y Treviño un momento transicional en el que convivieron los viejos y nuevos modelos, aunque con dos destacables novedades respecto a las anteriores formas de construir que probablemente deban entenderse juntas. Para empezar, se produjo un mayor empleo de la caliza paleocena en la construcción. De hecho, es infrecuente encontrar este material en las fases previas al 1100. Sólo en tres de las iglesias prerrománicas identificadas por L. Sánchez Zufiaurre ${ }^{54}$ se elaboraron sillares, sillarejos o vanos ex novo con caliza paleocena (la ermita de Andra Mari, la parroquia de Samiano y la segunda fase de San Román de Tobillas) (MartínezTorres 2004; Sánchez Zufiaurre 2007). Esto supuso una mayor intensidad en la explotación de las viejas canteras y, muy probablemente, la apertura de nuevos centros de extracción.

Paralelamente se comenzó a utilizar de forma masiva la escultura arquitectónica, prácticamente inexistente en los siglos anteriores más allá de las ventanas monolíticas. Las iglesias del siglo XII evidencian el aumento en la demanda de este tipo de producción edilicia para la realización de impostas, canes, cornisas, portadas, ventanales y otros elementos funcionales o decorativos.

Los principales cambios, sin embargo, se produjeron a lo largo del siglo XIII, cuando el mercado de la construcción especializada se transformó profundamente. Por un lado, tuvo lugar un cambio en la naturaleza de los promotores. Frente a los monasterios y nobles de la época anterior, son ahora mayoritariamente comunidades aldeanas, junto al poder diocesano, las que financiaron iglesias más funcionales pero técnica y estéticamente menos elaboradas. Por otro, cambió el modelo de organización del artesanado. Las cuadrillas itinerantes de constructores especializados perdieron importancia, acabaron desapareciendo y fueron sustituidas por talleres estables de ámbito local, mejor preparados para cubrir una demanda mayor y menos variable.

Por último, la diversidad de soluciones arquitectónicas, materiales, tipologías y formas decorativas, junto a la variedad de promotores y modelos organizativos de la mano de obra durante estos dos siglos, refleja hasta qué punto es imposible considerar las iglesias del denominado estilo románico como un unicum coherente y uniforme. Incluso después de haber sido agrupadas en periodos más breves, con límites fijados por criterios contrastables, dicha heterogeneidad continúa siendo notoria.

\footnotetext{
54 Se incluyen aquí sólo aquéllas insertas en los grupos 1, 2 y 3 por ser los únicos que con seguridad anteceden al siglo XII.
} 


\section{Muestra de fases constructivas} analizadas

\begin{tabular}{|c|c|c|c|c|c|c|c|c|c|c|c|c|c|c|}
\hline nalızadas & ADVOCACIÓN & 点 & 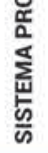 & 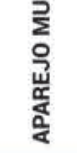 & 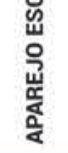 & 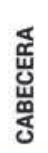 & 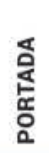 & 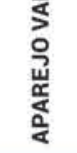 & 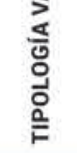 & $\frac{\Xi}{\rightleftarrows}$ & 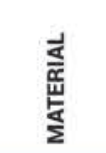 & 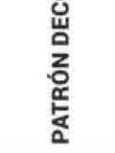 & 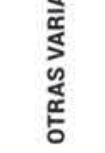 & $\begin{array}{l}\text { 음 } \\
\text { 음 } \\
\text { 땜 }\end{array}$ \\
\hline ABETXUKO & SANTÍSIMO CRISTO & E & 43 & 6 & 9 & 20 & . & - & . & 37 & 14 & - & - & P1 \\
\hline ABEZIA & SAN MARTIN & P & 43 & 4,6 & 10 & 20 & - & 24,29 & 35 & - & 15,17 & 63 & 46 & SP \\
\hline ACEBEDO & $\begin{array}{l}\text { SAN JUAN } \\
\text { EVANGELISTA }\end{array}$ & $P$ & 43 & 7 & - & 21 & 33 & - & - & 40 & 14 & - & - & P3 \\
\hline ALAITZA & $\begin{array}{l}\text { NTRA. SRA, } \\
\text { DELAASUNCIÓN }\end{array}$ & $P$ & 43 & 5,6 & 9 & 21 & 31 & 23,24 & 34 & 37 & 14 & 54,61 & 48 & PI \\
\hline ALBAINA & $\begin{array}{l}\text { NTRA. SRA. } \\
\text { DEL GRANADO }\end{array}$ & E & 42 & 1 & 9 & 20 & 30 & 24 & 35 & 39,40 & 14 & 59,62 & - & P3 \\
\hline ALEGRIA-DULANTZI & NTRA. SRA.DE AYALA & $E$ & 43 & 5,6 & 11 & 21 & 31 & 23,24 & 35 & 37 & 14 & 54,63 & $\begin{array}{l}46,47 \\
48,49\end{array}$ & P1 \\
\hline ANDA & SAN ESTEBAN & P & 44 & 6 & 10 & 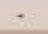 & - & 26 & - & - & 17 & - & 47 & SP \\
\hline ANTOÑANA & $\begin{array}{l}\text { NTRA. SRA. } \\
\text { DEL CAMPO }\end{array}$ & E & 43 & 5,6 & 9 & 21 & 32 & 23 & 34 & 37 & 14,18 & 54 & 47 & P1 \\
\hline AÑUA & $\begin{array}{l}\text { LA NATIVIDAD } \\
\text { DE NTRA. SRA. }\end{array}$ & $P$ & 43 & $1,5,6$ & 9 & 22 & $\cdot$ & 24 & 35 & 37,39 & 14 & $\cdot$ & 47,49 & P2 \\
\hline APRIKANO & SANTIAGO & P & 43 & 6 & 10 & 20 & 32 & 24 & 35 & 37 & $14,15,17$ & - & 47 & P1 \\
\hline ARAIA & SAN JUAN DE AMAMIO & E & 42 & 1 & 9 & 20 & 33 & 24 & 35 & 37 & 14,15 & 54,65 & 46,47 & P1 \\
\hline ARTXUA & SAN SEBASTIÁN & AP & 43 & 6 & 11 & 20 & 32 & 24 & 35 & - & 14,17 & - & 47 & P3 \\
\hline ARENAZA & SAN AGUSTÍN & P & 43 & 7,8 & - & - & 32 & - & - & 40 & 14 & - & - & P3 \\
\hline ARGANDOÑA & STA. COLUMBA & $P$ & 43 & 1,6 & 9 & 21 & 30 & 24 & 35 & 37,39 & 14,16 & 56 & 49 & P2 \\
\hline ARLUZEA & SAN MARTÍN & $P$ & 42 & 1 & 9 & 20 & - & 24 & 35 & 37 & 14,18 & 63,65 & 46,47 & P1 \\
\hline ARMENTIA & SAN PRUDENCIO & $P$ & 42 & 1 & 9 & 21 & - & 24 & 35 & 37 & 14,16 & 54,57 & 47,49 & P1 \\
\hline ARTAZA & $\begin{array}{l}\text { SAN COSME } \\
\text { Y SAN DAMIAN }\end{array}$ & AP & 43 & 5,6 & 11 & 20 & - & 24.29 & 35 & - & 14,17 & - & - & SP \\
\hline ATAURI & $\begin{array}{l}\text { LA ASUNCIÓN DE } \\
\text { NTRA. SRA. (FASE 1) }\end{array}$ & $P$ & 42 & 1 & 9 & - & . & - & - & 37 & 14 & - & - & P1 \\
\hline ATAURI & $\begin{array}{l}\text { LA ASUNCIÓN DE } \\
\text { NTRA. SRA. (FASE 2) }\end{array}$ & P & 43 & 7,8 & 13 & . & 31 & - & - & 39,40 & 14 & 56 & 48 & P3 \\
\hline ATAURI & LA SOLEDAD & $E$ & 43 & 7,8 & 9 & 21 & 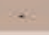 & 23 & 34 & 37 & 14 & 54,57 & - & P1 \\
\hline AZILU & SAN JUAN BAUTISTA & $P$ & 43 & 5 & 11 & 20 & 32 & $\begin{array}{c}23,24 \\
26\end{array}$ & 34,35 & 37,39 & 14,17 & 62 & 49 & P2 \\
\hline BELLOJIN & SAN CORNELIO & P & 43 & 5,6 & 9 & 21 & 30 & 24 & 35 & 37 & 14,16 & 54 & 46.47 & P1 \\
\hline BELUNTZA & SAN PEDRO & $P$ & 43 & - & 9 & 20 & 31 & 24 & 35 & 40 & $\begin{array}{l}14,15 \\
16,17\end{array}$ & $\begin{array}{l}54,55,56 \\
57,58,60\end{array}$ & $46,47,48$ & P3 \\
\hline BERANTEVILLA & $\begin{array}{l}\text { STA. MARIA } \\
\text { DE TOBERA }\end{array}$ & $E$ & 42 & 1 & 9 & 21 & - & 24 & 35 & 37 & 16 & 54,63 & $46,47,49$ & P1 \\
\hline BERRIKANO & $\begin{array}{l}\text { LA NATIVIDAD } \\
\text { DE NTRA. SRA. }\end{array}$ & $P$ & 43 & 6 & - & 20 & 33 & 24,29 & 35 & - & 14,15 & 54 & - & SP \\
\hline BURUAGA & SAN ESTEBAN & $P$ & 43 & 6 & 12 & 20 & - & - & - & - & 15 & - & - & SP \\
\hline CICUJANO & $\begin{array}{l}\text { LA DEGOLLACIÓN DE } \\
\text { SAN JUAN BAUTISTA }\end{array}$ & $P$ & 43 & 7 & 10 & 20 & 31 & 23,24 & 34 & 40 & 14 & 54 & 47 & P3 \\
\hline CORRO & SAN MIGUEL & P & 43 & 7 & 10 & 20 & . & - & - & 40 & 14 & - & - & P3 \\
\hline ELBURGO & $\begin{array}{l}\text { SAN JUAN } \\
\text { DE ARRARAIN }\end{array}$ & E & 43 & 1,7 & 9 & 21 & - & 24,26 & 35 & 37 & 14 & 54 & 47 & P1 \\
\hline ERENTXUN & SAN ANDRES & P & 42 & 1 & 9 & - & . & - & - & 40 & 14 & 54 & . & P3 \\
\hline ETXABARRI-KUARTANGO & SANTIAGO & $P$ & 43 & 7 & 11 & 20 & 32 & 24,26 & 35 & 37 & $14,15,17$ & - & - & P1 \\
\hline EZKEREKOTXA & SAN ROMÁN & $\mathbf{P}$ & 43 & $1,5,6$ & - & 22 & 30 & 24 & 35 & 39 & 14 & 54 & - & P3 \\
\hline GALARRETA & $\begin{array}{l}\text { NTRA. SRA. } \\
\text { DELAASUNCIÓN }\end{array}$ & AP & 42 & 1 & 9 & 20 & 32 & 24 & 35 & 37 & 14,15 & 54,55 & - & P1 \\
\hline GARDELEGI & SAN PEDRO & P & 43 & 6 & 11 & 20 & 32 & 25,29 & 35 & - & 14,17 & - & - & SP \\
\hline GAZEO & SAN MARTÍN DE TOURS & $P$ & 43 & 6 & 12 & 21 & 32 & 23,24 & 34 & 37,39 & $14,15,18$ & - & . & P2 \\
\hline GAZETA & SAN MARTÍN & $P$ & 43 & 6 & 11 & . & 32 & 24.29 & . & 40 & $14,15,17$ & 58,65 & 47 & P3 \\
\hline GOIURI-ONDONA & SANTIAGO & $P$ & 43 & 5,6 & 11 & 20 & 32 & 23,24 & 35 & - & $14,15,17$ & 54,63 & - & SP \\
\hline GOPEGI & $\begin{array}{l}\text { NTRA. SRA. } \\
\text { DELAASUNCIÓN }\end{array}$ & $P$ & 43 & 5,6 & 11 & - & 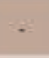 & 23 & $=$ & 40 & 14,15 & 63 & $46,47,53$ & P3 \\
\hline GUILLERNA & SANTIAGO & P & 43 & 6 & 9 & 20 & - & 24 & 35 & 41 & 15 & 56,57 & . & P3 \\
\hline HUETO ABAJO & SAN VICENTE & $P$ & 43 & $1,5,6$ & 9.11 & 22 & 31 & 24,29 & 35 & 37 & $14,15,17$ & 54,58 & $47,49,53$ & P1 \\
\hline HUETO ARRIBA & LANATIVIDAD & $P$ & 43 & $4,5,6$ & 10,11 & 21 & 30 & 24,29 & 35 & 37 & 14,17 & 58,63 & - & P1 \\
\hline JOKANO & SAN MARTIN & P & 43 & 6 & 10,11 & 20 & 30 & 24 & 34,35 & 37 & 14,17 & 54 & 47,51 & P1 \\
\hline JUGO & SAN MARTÍN & $P$ & 43 & 6 & - & - & 33 & 23,29 & . & 41 & 15 & . & . & $S P$ \\
\hline KARKAMU & SAN JUAN BAUTISTA & E & 42 & 1 & 9 & 21 & 32 & 24,26 & 35 & 37 & 14,16 & 54,63 & 46,47 & P1 \\
\hline
\end{tabular}




\begin{tabular}{|c|c|c|c|c|c|c|c|c|c|c|c|c|c|c|}
\hline LOCALIDAD & ADVOCACIÓN & 点 & 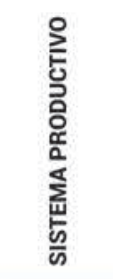 & 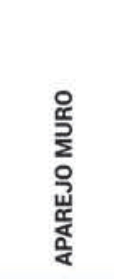 & 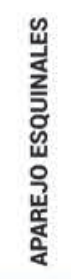 & 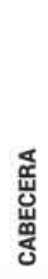 & 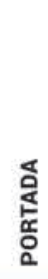 & 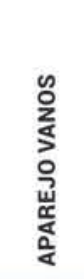 & $\begin{array}{l}\text { 山 } \\
0 \\
0 \\
z \\
\vdots \\
0 \\
0 \\
0 \\
0 \\
0 \\
0 \\
0\end{array}$ & $\underset{\Xi}{\stackrel{\Xi}{E}}$ & $\frac{\vec{s}}{\frac{\vec{L}}{\tilde{c}}}$ & 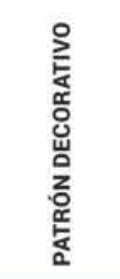 & 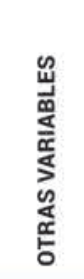 & $\begin{array}{l}\text { 음 } \\
\text { 음 } \\
\text { 몀 }\end{array}$ \\
\hline KATADIANO & SAN PEDRO APÓSTOL & $\mathrm{P}$ & 43 & 5,6 & 10 & 20 & - & 24 & 35 & 41 & $14,15,17$ & $\begin{array}{l}54,55, \\
57,58\end{array}$ & $\cdot$ & P3 \\
\hline KONTRASTA & $\begin{array}{l}\text { NTRA. SRA. } \\
\text { DE ELIZMENDI }\end{array}$ & E & 42 & 1,8 & 9 & 21 & - & 23 & 34 & - & 14,18 & - & 47 & P1 \\
\hline LABASTIDA & STA. LUCIA & E & 42 & 1 & 9 & 21 & - & 23 & 34 & 37 & 16 & - & - & P1 \\
\hline LAGUARDIA & $\begin{array}{l}\text { STA. MARIA } \\
\text { DE BERBERANA }\end{array}$ & E & 42 & 2 & 10 & 20 & 31 & 24 & - & 41 & 14,16 & - & 48 & SP \\
\hline LAÑ̃O & $\begin{array}{l}\text { NTRA. SRA. } \\
\text { DELAASUNCIÓN }\end{array}$ & $P$ & 42 & 1 & 9 & 20 & 30 & 24 & 35 & 37,39 & 14 & $\begin{array}{l}55,58, \\
61,65\end{array}$ & - & P2 \\
\hline LARREA & SAN MILLAAN & $P$ & 43 & 5,6 & 10 & - & - & 27 & - & - & 15 & - & - & SP \\
\hline LEGARDA & SAN ANDRÉS APÓSTOL & $\mathrm{P}$ & 43 & 6 & 11 & 20 & - & 24,25 & 36 & 40 & 14 & - & - & P3 \\
\hline LEORZA & SANTA EUFEMIA & $\mathrm{P}$ & 43 & 7 & 10 & . & 32 & 24 & . & 37 & 14 & 54,63 & . & P1 \\
\hline LETONA & SAN ANDRÉS & $P$ & 43 & 6 & 11 & - & - & 28 & - & . & 15 & - & 47 & SP \\
\hline LOPIDANA & LAPURIFICACIÓN & $P$ & 43 & 6 & . & . & 30 & . & . & 40 & 14 & 58 & - & P1 \\
\hline LUBIANO & LANATIVIDAD & $P$ & 42 & 1 & 9 & $\therefore$ & . & 24 & . & 37 & 14,15 & - & - & P1 \\
\hline LUKO & SAN MARTIN DE TOURS & $P$ & 43 & 6 & 10 & . & . & 24 & - & 37 & $14,15,17$ & 63 & 53 & PI \\
\hline MAEZTU & VIRGEN DEL CAMPO & E & 43 & - & 9 & 20 & - & 24 & 35 & 37 & 14 & $55,58,59$ & 47,48 & P1 \\
\hline MANDOJANA & SAN ESTEBAN & $P$ & 44 & 6 & 12 & 20 & . & : & . & 41 & 17 & . & - & SP \\
\hline MANZANOS & SAN JUAN & $\mathrm{P}$ & 42 & 1 & 9 & 20 & - & 24 & 35 & 37 & 16 & 54 & - & P1 \\
\hline MARINDA & $\begin{array}{l}\text { SAN JUAN ANTE } \\
\text { PORTAM LATINAM }\end{array}$ & AP & 43 & 6 & 11 & 20 & 32 & 24 & - & 40 & 14,17 & - & 53 & P3 \\
\hline MARKINEZ & SAN JUAN BAUTISTA & E & 42 & 1 & 9 & 21 & 30 & 24 & 35 & 37,40 & 14 & $54,55,58$ & 49 & P2 \\
\hline MARTIODA & $\begin{array}{l}\text { NTRA. SRA. } \\
\text { DE URRIALDO }\end{array}$ & E & 43 & 5,6 & 11 & 20 & 31 & 24,29 & 35 & 37 & $14,15,17$ & - & 47 & P1 \\
\hline MENDAROZKETA & $\begin{array}{l}\text { SAN JUAN } \\
\text { EVANGELISTA }\end{array}$ & $P$ & 43 & 6 & 9 & - & - & 23 & - & $\cdot$ & 15 & - & - & SP \\
\hline MENDIGUREN & $\begin{array}{l}\text { NTRA. SRA. } \\
\text { DE LA ASUNCIÓN }\end{array}$ & $P$ & 43 & 6 & 11 & $\therefore$ & 31 & 24 & . & 39 & 14,15 & . & 47 & P3 \\
\hline MIÑANO MENOR & SAN VICENTE MÁRTIR & $P$ & 43 & 5 & 10 & 20 & $\therefore$ & 24 & 35 & 39 & 14,15 & $\begin{array}{c}54,55,56 \\
58,60\end{array}$ & 47 & P3 \\
\hline MONASTERIOGUREN & $\begin{array}{l}\text { SAN PEDRO APOSTOL } \\
\text { (FASE 1) }\end{array}$ & $P$ & 43 & 6 & 12 & 20 & 30 & 24 & - & 37 & 14 & 58 & 47 & P1 \\
\hline MONASTERIOGUREN & $\begin{array}{l}\text { SAN PEDRO APÓSTOL } \\
\text { (FASE 2) }\end{array}$ & $P$ & $\begin{array}{c}42 \\
\text { (PORTICO) } \\
\text { 43(TORRE) }\end{array}$ & $\begin{array}{c}1 \\
\text { (PORTCO). } \\
6 \text { (TORPE) }\end{array}$ & 9 & - & - & 24 & - & 40 & 14 & $\begin{array}{l}54 \\
\text { (TORRE) }\end{array}$ & - & P3 \\
\hline MORAZA & SAN JUAN & $P$ & 42 & 1.2 & 9,11 & 20 & 33 & 24 & 35 & 37 & 14,16 & - & 47 & P1 \\
\hline MUSITU & SAN MARTIN & $P$ & 42 & 1 & 9 & 20 & 32 & 23 & 34 & 40 & 14 & 54 & 48 & P3 \\
\hline NANCLARES DELA OCA & $\begin{array}{l}\text { LA ASUNCIÓN } \\
\text { DENTRA. SRA. }\end{array}$ & $\mathrm{P}$ & 43 & $5,6,7$ & - & 21 & - & 24 & 35 & 37 & $14,16,19$ & 58 & 49 & P1 \\
\hline OBÉCURI & SAN JUAN (FASE 1) & $P$ & 42 & 1 & 9 & 20 & 30 & - & - & 37 & 14 & 59 & - & P1 \\
\hline OBÉCURI & SAN JUAN (FASE 2) & $P$ & 42 & 1 & 9 & 20 & 30 & 24 & . & 40 & 14 & $54,55,58$ & 48 & P3 \\
\hline OIARDO & $\begin{array}{l}\text { NTRA. SRA. } \\
\text { DE GOIKOGANA }\end{array}$ & E & 45 & 6 & 11,12 & 20 & - & 29 & . & - & . & - & . & SP \\
\hline OIARDO & SAN JUAN BAUTISTA & $P$ & 43 & 5,6 & 11 & 20 & 32 & 24 & 35 & - & 14,17 & $56,57,60$ & - & P3 \\
\hline OKINA & LAASUNCIÓN & $P$ & 42 & 1 & 9 & 20 & 30 & 23,24 & 35 & 37,39 & 14 & 55,58 & 48 & P2 \\
\hline OLANO & SAN BARTOLOMÉ & $P$ & 43 & 5,6 & 10 & 20 & - & $\begin{array}{c}23,24 \\
29\end{array}$ & 35 & - & 15,17 & $\begin{array}{l}54,57, \\
60,63\end{array}$ & 47 & P3 \\
\hline ONDATEGI & SAN LORENZO & $P$ & 43 & 6 & 11 & - & 30 & 29 & - & - & 14,15 & 54,60 & 47 & SP \\
\hline OTAZU & SAN MARTIN DE TOURS & P & 43 & 6 & 11 & - & 30 & - & . & 39 & 14 & - & 48,53 & P3 \\
\hline RIBERA & SAN ESTEBAN & AP & 43 & 2,4 & 10 & 20 & 30 & 24 & 35 & 37,40 & 14,18 & . & 48,53 & P2 \\
\hline SALVATIERRA & SAN MARTÍN (FASE 1) & E & 42 & 1 & 9 & 20 & 33 & 24 & 35 & 37 & 14 & 54,65 & - & P1 \\
\hline SALVATIERRA & SAN MARTIN (FASE 2) & E & 43 & 5 & 9,13 & 20 & - & 23, 24 & 35 & 40 & 14 & - & - & P3 \\
\hline SAN MARTÍN DE ZAR & SAN MARTIN & $\mathrm{P}$ & 42 & 1 & 9 & 21 & - & 24 & 35 & 37 & 14,16 & - & 47,49 & P1 \\
\hline SAN MIGUEL. & SAN MIGUEL & $P$ & 44 & 4,5 & 10 & 20 & . & 26 & - & - & 16 & - & 47,53 & SP \\
\hline SAN VICENTEJO & LACONCEPCIÓN & E & 42 & 1 & 9 & 21 & 30 & 24 & 35 & 37,39 & 14 & 54 & $\begin{array}{l}46,47, \\
49,53\end{array}$ & P2 \\
\hline SANTURDE & SAN JORGE & $P$ & 42 & 1 & 9 & $\cdot$ & 30 & - & . & 37 & 14,16 & 54,62 & - & P1 \\
\hline SARASO & SAN ANDRÉS & $P$ & 43 & 7 & . & 20 & 30 & 23,24 & 34,35 & 40 & 14 & 59,61 & 48,50 & P3 \\
\hline SENDADIANO & SAN MARTÍN & $\mathbf{P}$ & 43 & 6 & 11 & 20 & 32 & 24 & - & - & 15,17 & - & 51 & P3 \\
\hline
\end{tabular}




\begin{tabular}{|c|c|c|c|c|c|c|c|c|c|c|c|c|c|c|}
\hline LOCALIDAD & ADVOCACIÓN & 蛋 & 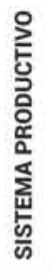 & 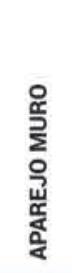 & 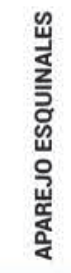 & 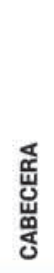 & 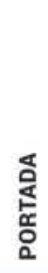 & 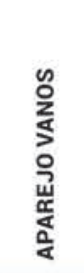 & 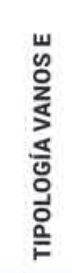 & $\underset{⿱}{\stackrel{\Xi}{E}}$ & 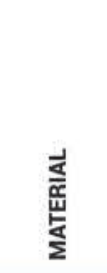 & 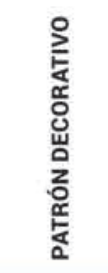 & 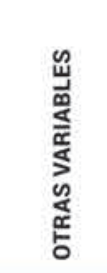 & $\begin{array}{l}\text { 음 } \\
\text { 염 }\end{array}$ \\
\hline SOBRÓN & $\begin{array}{l}\text { SAN MARTÍN } \\
\text { DELANTARÓN }\end{array}$ & E & 43 & $2,5,7$ & 9 & 21 & 30 & 23,29 & 34 & 37 & 14,16 & 63 & $46,47,52$ & P1 \\
\hline SUBIJANA-MORILLAS & LAASUNCIÓN & $P$ & 43 & 6 & 10 & 20 & - & $\begin{array}{l}23,24, \\
26\end{array}$ & 34,35 & 40 & $14,16,17$ & - & - & P3 \\
\hline TOBILLAS & SAN ROMÁN & $P$ & 42 & 1 & 9 & - & 32 & - & - & 37 & 14 & 54 & $46,47,53$ & PI \\
\hline TORTURA & SAN ANDRÉS & $P$ & 43 & 6 & 11 & 20 & 32 & 24,29 & 35 & 41 & 15,17 & 56,57 & 47,51 & P3 \\
\hline TROKONIZ & SAN VICENTE & $P$ & 42 & 1 & 9 & 21 & - & 23 & 35 & 37 & 14 & 54 & 49 & P1 \\
\hline TUESTA & NTRA. SRA. & $P$ & 42 & 1 & 9 & 22 & 30 & 24 & 35 & 37 & 14,16 & 54 & $\begin{array}{l}47,48 \\
49,53\end{array}$ & P1 \\
\hline ULLIBARRI-ARANA & ANDRA MARI & E & 43 & 8 & 13 & 21 & 32 & 23 & 34 & 37 & 14 & 54 & $\cdot$ & P1 \\
\hline ULLLIBARRI-VINTA & $\begin{array}{l}\text { NTRA. SRA. } \\
\text { DELAASUNCIÓN }\end{array}$ & $P$ & 43 & 6 & 9 & 20 & $\cdot$ & 24 & 35,36 & 37 & $14,15,17$ & - & - & P1 \\
\hline UNZÁ & SAN FAUSTO & P & 43 & 6 & 11 & 20 & 30 & 24 & 35,36 & . & $14,15,17$ & 63 & 47 & SP \\
\hline URARTE & $\begin{array}{l}\text { NTRA. SRA. } \\
\text { DELARRAURI }\end{array}$ & E & 42 & 1 & 9 & 20 & - & 24 & 35 & 37 & 14 & 63 & - & P1 \\
\hline URBINA DE BASABE & SAN PEDRO & AP & 43 & 6 & 10,11 & 20 & $\cdot$ & 26 & 34 & - & 14 & - & . & SP \\
\hline URBINA EZA & $\begin{array}{l}\text { SAN JUAN } \\
\text { EVANGELISTA }\end{array}$ & $P$ & 43 & 7 & 11 & - & 32 & 24 & - & - & $\begin{array}{l}14,15 \\
16,17\end{array}$ & - & - & P3 \\
\hline URIBARRI-KUARTANGO & $\begin{array}{l}\text { SAN QUIRICO } \\
\text { Y STA. JULITA }\end{array}$ & P & 43 & 5,6 & 10 & 20 & 30 & 23,24 & 35 & 37 & $\begin{array}{l}14,16 \\
17,19\end{array}$ & 54 & 47 & P1 \\
\hline UZKIANO (TREVIÑO) & $\begin{array}{l}\text { SAN MIGUEL } \\
\text { ARCANGEL. }\end{array}$ & $P$ & 43 & 6 & 11 & 20 & 30 & 24 & 35 & - & 14,17 & - & - & SP \\
\hline UZQUIANO & $\begin{array}{l}\text { LAASUNCIÓN } \\
\text { DENTRA. SRA. }\end{array}$ & $P$ & 43 & 5,6 & 10 & 20 & 30 & 24 & 35 & 37,40 & 14 & 59,61 & 48 & P2 \\
\hline VALLUERCA & STA. MARIA & P & 43 & 7 & 11 & 21 & 33 & 23,24 & 34 & 37 & 14 & $54,57,63$ & 47 & P1 \\
\hline VILLAMANCA & SANTIAGO & $\mathrm{P}$ & 43 & 6 & 11 & 20 & . & 24 & 35 & 40 & 14,17 & - & . & P3 \\
\hline VIRGALA MAYOR & SAN ANDRÉS & $P$ & 42 & 1 & 9 & 20 & 30 & 24 & 35 & 37,40 & 14 & $54,58,62$ & 48,50 & $\mathrm{P} 2$ \\
\hline VIRGALA MENOR & $\begin{array}{l}\text { LA CONCEPCIÓN } \\
\text { DE NTRA. SRA. }\end{array}$ & AP & 42 & 1 & 9 & 20 & $\cdot$ & - & - & - & 14 & - & 47 & SP \\
\hline VITORIA-GASTEIZ & $\begin{array}{l}\text { SAN MARTíN } \\
\text { DEABENDANNO }\end{array}$ & E & 43 & 5,6 & 9 & 20 & , & 24 & 35 & 37 & 14 & - & - & P1 \\
\hline ZALDUONDO & $\begin{array}{l}\text { SAN JULIAN } \\
\text { Y SANTA BASILISA }\end{array}$ & E & 43 & 8 & 13 & 20 & - & · & - & . & 15 & · & 47 & P1 \\
\hline ZESTAFE & SAN NICOLÁS OBISPO & P & 43 & 6 & 11 & 20 & 30 & 24,29 & 35,36 & - & 15,17 & 63 & 47 & SP \\
\hline ZESTAFE & $\begin{array}{l}\text { SAN PEDRO } \\
\text { DE GOROSTIZA }\end{array}$ & E & 43 & 7,8 & 13 & 20 & 32 & 24 & 35 & - & 15 & - & - & P3 \\
\hline ZUAZO DE VITORIA & SAN ESTEBAN & $P$ & 43 & 5,6 & 11 & . & 30 & - & - & 37 & 14 & - & 48 & P1 \\
\hline ZUHATZU-KUARTANGO & SAN PEDRO APÓSTOL & P & 43 & 6 & 11 & 20 & 30 & 24 & 35 & - & $14,15,17$ & $55,57,58$ & - & P3 \\
\hline
\end{tabular}

\section{ESTATUS}

AP Antigua parroquia.

E Ermita.

P Parroquia.

\section{APAREJO MURO}

1 Sillería.

2 Sillarejo.

4 Mampostería escuadrada.

5 Mampostería semielaborada

6 Bloques extraidos

por capas naturales.

7 Material recogido.

8 Material reutilizado.

APAREJO ESQUINALES
9 Sillería.
10 Sillarejo.
11 Mampostería escuadrada.
12 Bloques extraídos
por capas naturales.
13 Material reutilizado.
MATERIAL
14 Caliza paleocena.
15 Arenisca albiense.
16 Arenisca miocena.
17 Calizas del cretácico superior.
18 Travertino.
19 Aragonito.
MORFOLOGÍA CABECERA
20 Recta.
21 Semicircular.
22 Ochavada.

APAREJO VANOS

23 Silleria.

24 Sillería y piezas escultóricas.

25 Sillería, mampostería

y piezas escultóricas.

26 Sillería y mampostería de diverso tratamiento

27 Elementos reutilizados.

28 Elementos reutilizados

y mampostería.

29 Mampostería.

\section{MORFOLOGÍA PORTADA}

30 Arquivoltas, columnas.

31 Arquivoltas, baquetones.

32 Arquivoltas, jambas de arista.

33 Arco, jambas de arista.

\section{TIPOLOGÍA VANOS AL}

34 Saetera(s) al E.

35 Ventanal(es) al E.

36 Óculo(s) al E.

INSTRUMENTOS DE TALLA
37 Tallante.
39 Trinchante.
40 Gradina.
41 Pico.
SISTEMA PRODUCTIVo
42 Cantero.
43 Mixto con material local
y alóctono.
44 Mixto con material local.
45 Albañil.
OTRAS VARIABLES
46 Cornisa decorada.
47 Canes decorados.
48 Marco de sillería en portada.
49 Elementos decorativos
adicionales.
50 Tímpano en portada.
51 Portada al W.
52 Portada al $\mathrm{N}$.
53 Contrafuertes.

PATRÓN DECORATIVO

54 Ajedrezado.

55 Círculos.

56 Encestado.

57 Sogueado

58 Hojas de acanto con la parte superior doblada.

59 Clavos.

60 Hojas lanceoladas.

61 Taqueado simple.

62 Flores en aspa.

63 Semiesferas.

65 Motivos vegetales organizados en círculos entrelazados.

PERIODO

P1 Periodo 1 (ca. 1100-1250).

P2 Periodo 2 (ca. 1220-1250).

P2 Periodo 2 (ca. 1220-1250).

SP Sin periodo asignado. 


\section{AGRADECIMIENTOS}

Trabajo realizado en el marco del proyecto de investigación, financiado por el Ministerio de Economía, Industria y Competitividad, "Agencia campesina y complejidad sociopolítica en el noroeste de la Península Ibérica en época medieval" (HAR2016-76094-C4-2-R) y del Grupo de Investigación en Patrimonio y Paisajes Culturales (IT931-16) de la Universidad del País Vasco / Euskal Herriko Unibertsitatea. Deseo agradecer enormemente a Juan Antonio Quirós, Giovanna Bianchi, Leandro Sánchez, Javier Ordoño y Teresa Fernández sus valiosas aportaciones para mejorar el texto.

\section{BIBLIOGRAFÍA}

Ajamil, F. J. 2012: Análisis estratigráfico de los alzados de la iglesia de San Sebastián (Artxua, Kuartango). Memoria de resultados, inédito.

Alfaro, E. 2009: "La iglesia en su paisaje medieval. El estudio de AgurainSalvatierra (Álava) a través de la lectura estratigráfica de alzados de la ermita de San Martín”, Munibe (Antropologia-Arkeologia), 59, pp. 247-267.

Alfaro, E. 2016: La formación de la red parroquial en Álava y Treviño. Evidencias desde la arqueología (siglos XI-XIII), tesis doctoral defendida en la Universidad del País Vasco / Euskal Herriko Unibertsitatea el 15 de enero de 2016, inédita.

Azkarate, A. 1995: "Aportaciones al debate sobre la arquitectura prerrománica peninsular: la iglesia de San Román de Tobillas (Álava)", Archivo Español de Arqueología, 68, pp. 189-214.

Azkarate, A., Fernández de Jauregui, A. y Núñez, M. 1995: "Documentación y análisis arquitectónico en el País Vasco. Algunas experiencias llevadas a cabo en Álava-España”, Informes de la construcción, 46, pp. 65-77, doi: https://doi.org/10.3989/ic.1995.v46.i435.1099.

Azkarate, A. y Sánchez Zufiaurre, L. 2003: "Las iglesias prefeudales en Álava. Cronotipología y articulación espacial”, Arqueología de la Arquitectura, 2, pp. 25-36, doi: https://doi.org/10.3989/arq.arqt.2003.21.

Bessac, J. C. 1986: L'outillage traditionnel du tailleur de pierre. De l'Antiquité à nos jours. Revue archéologique de Narbonnaise. Supplément 14, Centre National de la Recherche Scientifique.

Bianchi, G. 1995: 'L'analisi dell'evoluzione di un sapere tecnico per una rinnovata interpretazione dell'assetto abitativo e delle strutture edilize del villaggio fortificato di Rocca S. Silvestro", en Boldrini, E. y Francovich, R. (eds.), Acculturazione e mutamenti. Prospettive nell'archeologia medievale del Mediterraneo, VI ciclo di lezioni sulla ricerca applicata in archeologia, pp. 361-396. Firenze, All'Insegna del Giglio.

Brogiolo, G. P. 1988: Archeologia dell'edilizia storica. Documenti e metodi. Como, New Press.

Brogiolo, G. P. 1995: “Arqueología estratigráfica y restauración”, Informes de la Construcción, 46, pp. 31-36, doi: https://doi.org/10.3989/ic.1995. v46.i435.1095.

Caballero, L. y Utrero, M. A. 2005: "Una aproximación a las técnicas constructivas de la Alta Edad Media en la Península Ibérica. Entre visigodos y omeyas", Arqueología de la Arquitectura, 4, pp. 169-192, doi: https://doi. org/10.3989/arq.arqt.2005.82.

Castiñeiras, M. 2012: "San Vicentejo de Treviño, un edificio excepcional en la encrucijada del tardorrománico hispánico", en Viaje a Íbita. Estudios históricos del Condado de Treviño, pp. 229-288. Ayuntamiento Condado de Treviño.

Díaz de Durana, J. R. y Guinot, E. 2010: “La dîme dans 1'Espagne médiévale", en Viader, R. (ed.), La dîme dans l'Europe médiévale et moderne. Actes des XXXes Journées Internationales d'Histoire de l'Abbaye de Flaran, 3 et 4 octobre 2008, pp. 63-88. Toulouse, Presses Universitaires du Mirail.

Farías, V. 1993: "La sagrera catalana (c. 1025 - c. 1200): características y desarrollo de un tipo de asentamiento eclesial", Studia Historica - Historia Medieval, XI, pp. 81-121.

Farías, V. 2007: “La proclamació de la pau i l'edificació dels cementiris. Sobre la difusió de les sagreres als bisbats de Barcelona i Girona (segles XI-XIII)", en Farías, V., Martí, R., y Catafau, A. (eds.), Les sagreres a la Catalunya medieval, pp. 13-84. Girona, Associació d'Historia Rural de les Comarques Gironines.

Ferrando, I., Mannoni, T., y Pagella, R. 1989: "Cronotipologia", Archeologia Medievale, XVI, pp. 647-661.

García Guinea, M. A. y Pérez González, J. M. 2002: Enciclopedia del Románico en Castilla y León. Burgos. Volumen III. Aguilar de Campoo, Fundación Santa María La Real.

García Guinea, M. A. y Pérez González, J. M. 2011: Enciclopedia del Románico en el País Vasco. Aguilar de Campoo, Fundación Santa María La Real.

Gómez Gómez, A. 1995-1997: “Asimilación y transmisión del arte románico en el País Vasco: el caso de Estíbaliz (Álava)”, Kobie (Serie Bellas Artes), XI, pp. 241-254.

Gómez Gómez, A. 2000: Rutas románicas en el País Vasco. Madrid, Encuentro.

Lasagabaster, J. I., Azkarate, A., y De la Fuente Arana, A. 2006: Plan Director de intervención para la restitución de los valores históricos y simbólicos de la Basilica de San Prudencio de Armentia y su entorno, Grupo de Investigación en Arqueología de la Arquitectura de la Universidad del País Vasco.

López de Ocáriz, J. J. 2014: “Un ejemplo del románico inicial en Álava: el ábside con modillones de ornamentación bifacial en Nuestra Señora de Elizmendi, Kontrasta", Brocar, 38, pp. 11-43.

López de Ocáriz, J. J. y Martínez de Salinas, F. 1988: “Arte prerrománico y románico en Álava”, Ondare: cuadernos de artes plásticas y monumentales, 5, pp. 15-88.

Mannoni, T. 1997: "Il problema complesso delle murature storiche in pietra. 1. Cultura materiale e cronotipologia", Archeologia dell'Architettura, 2, pp. $15-24$.

Martínez-Torres, L. M. 2003: "Sobre los mapas litológicos de las parroquias de la Diócesis de Vitoria-Gasteiz", Arqueología de la Arquitectura, 2, pp. 185-187.

Martínez-Torres, L. M. 2004: La tierra de los pilares. Sustratos y rocas de construcción monumental en Álava. Mapas litológicos de las iglesias de la Diócesis de Vitoria. Bilbao, Universidad del País Vasco.

Martínez-Torres, L. M. 2007: "Lithological maps of churches in the Diocese of Vitoria (Spain): Space-time distribution of building stones and ancient quarries", Building and Environment, 42, pp. 860-865, doi: https://doi. org/10.1016/j.buildenv.2005.10.004.

Martínez-Torres, L. M. 2009a: La ruta de la piedra. Camino medieval desde las canteras antiguas de Ajarte hasta la Catedral Vieja de Santa María de Vitoria-Gasteiz. Bilbao, Universidad del País Vasco.

Martínez-Torres, L. M. 2009b: "The Typology of Ancient Quarries within the Paleocene Limestone of Álava in Northern Spain", Geoarchaeology: An International Journal, 24, pp. 42-58, doi: https://doi.org/10.1002/ gea.20252.

Martínez-Torres, L. M. 2011: "Litolipos, composiciones litológicas excepcionales y canteras antiguas del románico alavés" en García Guinea, M. A. y Pérez González, J. M. (eds.), Enciclopedia del Románico en el País Vasco, pp. 101-116. Aguilar de Campoo, Fundación Santa María La Real.

Moreno, F. J. 2014: “Arqueología de la Arquitectura. Una visión conciliadora desde la Historia del Arte", Arqueología de la Arquitectura, 11: e009, doi: https://doi.org/10.3989/arq.arqt.2014.008.

Murillo, J. I. 2004: "Iglesia de San Martín de Arlucea (Bernedo)", Arkeoikuska 2003, 252-254.

Núñez, J. 2000: "Ermita de Andra Mari en Ullíbarri Arana (Valle de Arana)", Arkeoikuska 1999, pp. 264-265.

Ocón, D. 1996: "La arquitectura románica vasca: tipos, modelos y especifidades", Ondare: cuadernos de artes plásticas y monumentales, 15, pp. 51-78. 
O'Keeffe, T. 2007: Archaeology and the Pan-European Romanesque. London, Duckworth.

Pastor, E. 2011: "La Llanada oriental hace mil años. ¿Qué hay del crecimiento agrario altomedieval? Hábitat y paisajes agrarios (entre la imaginación y la lógica)", en Actas del Congreso 750 aniversario de la fundación de la villa de Salvatierra, pp. 55-75. Ayuntamiento de Salvatierra.

Portilla, M. J. 1984: "Arte Románico. Raíces y evolución”, en Llanos, A. (ed.), Álava en sus manos. Vitoria-Gasteiz, Caja Provincial de Ahorros de Álava.

Portilla, M. J. y Eguía, J. 1968: Catálogo monumental de la Diócesis de Vitoria. Tomo II. Arciprestazgos de Treviño, Albaina y Campezo. VitoriaGasteiz, Obra Cultural de la Caja de Ahorros Municipal de Vitoria.

Quirós, J. A. 2001: "La sillería en la arquitectura altomedieval en el Mediterráneo occidental", en Actas del V Congreso de Arqueología Medieval Española, Valladolid, 1999, pp. 281-291. Valladolid, Junta de Castilla y León.

Quirós, J. A. 2002. "Arqueología de la Arquitectura en España", Arqueología de la Arquitectura, 1, pp. 27-38, doi: https://doi.org/10.3989/arq. arqt.2002.4.

Quirós, J. A. 2007: "La Arqueología de la Arquitectura y la Arqueología Medieval (por qué hacer Historia a partir del registro arquitectónico de época medieval)", en Molina, A. L. y Eiroa, J. A. (eds.), Tendencias actuales en Arqueología Medieval, pp. 23-57. Universidad de Murcia.

Quirós, J. A. 2008: "Despoblado de Zornoztegi", Arkeoikuska 2007, pp. 114-122.

Sánchez Zufiaurre, L. 2004: "Iglesia de San Martín de Gáceta (Elburgo)", Arkeoikuska 2003, pp. 254-256.
Sánchez Zufiaurre, L. 2007: Técnicas constructivas medievales. Nuevos documentos arqueológicos para el estudio de la Alta Edad Media en Álava. Vitoria-Gasteiz, Gobierno Vasco.

Sánchez Zufiaurre, L. 2009: "La iglesia prerrománica de Valluerca (Álava). Un nuevo ejemplo de campanario altomedieval", Arqueología de la Arquitectura, 5, pp. 79-89, doi: https://doi.org/10.3989/arq.arqt.2008.90.

Sánchez Zufiaurre, L. 2012: "Los talleres de construcción en Treviño. Del prerrománico al siglo XV a través de la arqueología", en Viaje a Íbita. Estudios históricos del Condado de Treviño, pp. 143-178. Ayuntamiento Condado de Treviño.

Sánchez Zufiaurre, L. y Benedet, V. 2009a: "Iglesia de La Asunción (Atauri)", Arkeoikuska 2008, pp. 52-56.

Sánchez Zufiaurre, L. y Benedet, V. 2009b: "Iglesia de Santa Columba (Argandoña)", Arkeoikuska 2008, pp. 195-200.

Sánchez Zufiaurre, L., Domínguez, I. C. y Gobbato, S. 2002: "Iglesia de Mandojana (Vitoria-Gasteiz)", Arkeoikuska 2001, pp. 305-312.

Sánchez Zufiaurre, L. y Neira, M. 2009: "Iglesia de San Juan (Mendarozketa)", Arkeoikuska 2008, pp. 212-215.

Solaun, J. L. 2003: "Iglesia de San Vicente, en Hueto de Abajo (VitoriaGasteiz)", Arkeoikuska 2002, pp. 316-323.

Utrero, M. A. 2010: "Late-Antique and Early Medieval Hispanic Churches and the Archaeology of Architecture: Revisions and Reinterpretation of Constructions, Chronologies and Contexts", Medieval Archaeology, 54, pp. 1-33, doi: https://doi.org/10.1179/174581710x12790370815652.

Vargas, C. 2013: "Reflexiones sobre cronotipologías en Arqueología de la Arquitectura. Métodos y sistemas de análisis", Arqueología de la Arquitectura, 10, e001, doi: https://doi.org/10.3989/arq.arqt.2013.001. 